\title{
GROUND WATER FOR IRRIGATION IN LODGEPOLE VALLEY, WYOMING AND NEBRASKA.
}

By Oscar E. Metnzer.

\section{INTRODUCTION.}

\section{IOCATION AND CHARACTER OF VALLEY.}

Lodgepole Creek rises in the Laramie Mountains, in Wyoming, and flows eastward and southeastward across the Great Plains to its junction with South Platte River. (See fig. 3.) Its course across the

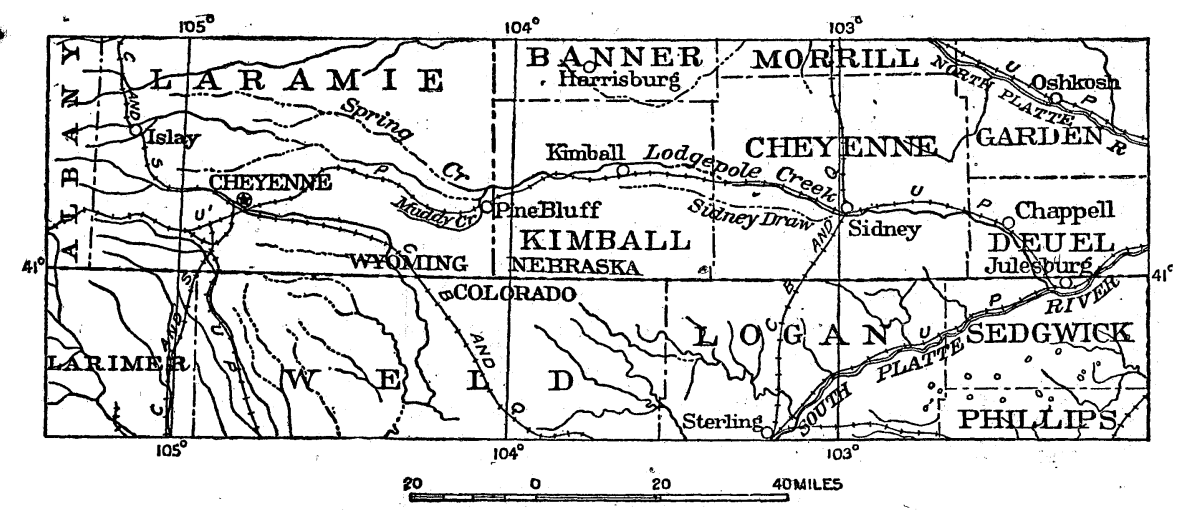

FIGURE 3.-Map showing the drainage basin of Lodgepole Creek and adjacent areas:

plains, not including meanders, is about 165 miles long, of which 65 miles is in Wyoming, 95 miles in Nebraska, and 5 miles in Colorado. Its valley resembles other valleys of the Great Plains in that it is a flat-bottomed, steep-sided trench, formed by stream erosion and later partly refilled by stream sedimentation.

Lodgepole Valley is traversed by the main line of the Union Pacific Railroad from Egbert, Wyo., to the place at which it opens into the broad, flat valley of the South Platte above Julesburg, Colo., and by the Lincoln Highway from Egbert, Wyo., to Chappell, Nebr. It is crossed at Sidney, Nebr., by the Chicago, Burlington \& Quincy Railroad, and near the mountains by the Colorado \& Southern Railway. Along the Union Pacific line in Lodgepole Valley there are many ranches and several towns, the largest of which is the enter- 
prising little city of Sidney. Thirty miles west of Egbert the Union Pacific line passes through Cheyenne, the capital of Wyoming. Above Egbert the valley is settled only at a few cattle and sheep ranches.

\section{PURPOSE AND SCOPE OF INVESTIGATION.}

In recent years the residents of Lodgepole Valley have been interested in projects for extending irrigation by pumping shallow ground water or by discovering artesian water, and have repeatedly requested the Federal Government to investigate the subject. It has not been practicable for the Geological Survey to make a thorough study of the ground-water supply of this valley, but in September, 1915, the writer made a brief field investigation, the general results of which are presented in this paper. The data on cost of pumping for irrigation, by H. C. Diesem (pp. 67-69), were generously furnished by the division of irrigation investigations, Office of Public Roads and Rural Engineering, United States Department of Agriculture.

\section{PHYSIOGRAPHY.}

The drainage basin of Lodgepole Creek comprises a long; narrow belt between the much larger basins of the North Platte and the South Platte, from which it is separated by inconspicuous divides. It is about 175 miles long, $12 \frac{1}{2}$ miles in average width, and approximately 2,200 square miles in area. ${ }^{i}$ It includes narrow segments of two very distinct physiographic provinces, the Laramie Mountains and, the Great Plains. The mountain segment is about 13 miles long and 5 miles in average width, and comprises about 65 square miles, or 3 per cent of the total drainage basin. All the rest of the drainage basin is in the Great Plains. The mountain segment ranges in altitude from about 7,000 to 8,000 feet above sea level; the upland surface of the plains segment from about 7,000 feet near the mountain front to less than 4,000 feet near the mouth of Lodgepole Creek.

The steep-walled, flat-bottomed valley that the creek has cut into the generally smooth surface of the plains averages about $1 \frac{1}{2}$ miles in width and ranges in depth from less than 100 feet to fully 250 feet.

The flood plain of the creek is bordered by terraces that stand at different elevations. In the upper part of the valley there are two rather definite terrace levels. In the vicinity of Ariosa and Pole Creek ranches the first terrace is about 15 feet above the stream, or 10 feet above the flood plain, and the second terrace is 30 to 50 feet above the stream. Below Pinebluff the second terrace is about 65 feet above the stream, and is well marked throughout most of Kimball County. In the vicinity of Sidney there is but one distinct terrace, and it is only 10 to 20 feet above the flood plain.

The upland surface of the Great Plains is interrupted by two prominent escarpments, about 250 feet high, one near Islay and the other

1 Price. D.. D. Nebraska Board of Irrigation, Highways, and Drainage Tenth Bienn. Rept., p. 37, 1914. 
near Pinebluff. These escarpments trend transverse to the course of the valley and face the west. On the west side of each is a low, flat plain that coincides in level with the floor of Lodgepole Valley and forms essentially an expanded part of the valley. The upland on the east side of each escarpment is a part of the general surface of the Great Plains, which slopes gently toward the east. The descent from the upland surface east of the Islay escarpment to the lowland surface on the west side of the Pinebluff escarpment is for the most part gradual, but there is an east-facing escarpment of some prominence in the vicinity of Egbert. These escarpments appear to be erosion features in the nature of hogbacks. The valley is deepest and narrowest where Lodgepole Creek cuts through the upland back of the Islay escarpment.

\section{GEOLOGY.}

Lodgepole Valley is underlain by sedimentary formations of great aggregate thickness, which rest on pre-Cambrian granite and other crystalline rocks. The following generalized section of these formations in the vicinity of the Laramie Mountains in southeastern Wyoming is given by Darton and Siebenthal. ${ }^{1}$ The Ogalalla formation, which occurs extensively along Lodgepole Valley, has been added to the section.

Generalized section of formations that outcrop in the vicinity of the Laramie Mountains and extend beneath the Great Plains.

[After N. H. Darton and C. E. Siebenthal.]

\begin{tabular}{|c|c|c|c|}
\hline System. & Formation. & Character of rocks: & $\begin{array}{l}\text { Thickness, } \\
\text { in feet. }\end{array}$ \\
\hline Tertiary.. & $\left\{\begin{array}{l}\text { Ogalalla formation } a . \\
\text { Arikaree formation.. } \\
\text { Brule clay.............. } \\
\text { Chadron sandstone.. }\end{array}\right.$ & $\begin{array}{l}\text { Poorly assorted deposits of clay, sand, and } \\
\text { gravel with much calcareous cement. } \\
\text { Sand, gravel, and boulder beds, with local } \\
\text { limestone lens. } \\
\text { Massive pinkish sandy clay, with gravelly } \\
\text { streaks. } \\
\text { Massive brown sandstone, merging into sand } \\
\text { and gravel. }\end{array}$ & $\begin{array}{r}0-300 \\
200-250 \\
250 \\
20-100\end{array}$ \\
\hline Cretaceous.. & $\left\{\begin{array}{l}\text { Fox Hills sandstone. } \\
\text { Pierre shale.......... } \\
\text { Niobrara limestone.. } \\
\text { Benton shale......... } \\
\text { Cloverly formation.. }\end{array}\right.$ & 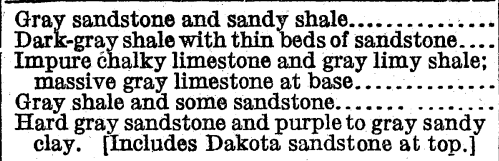 & $\begin{array}{r}700+ \\
5,000 \\
325-400 \\
700-1,000 \\
70-100\end{array}$ \\
\hline Cretaceous or Jurussic... & Morrison formation.. & $\begin{array}{l}\text { Massive pale green to maroon shale with thin } \\
\text { limestones and sandstones. }\end{array}$ & $150-200$ \\
\hline Jurassic........ & Sundance formation. & Buff slabby sandstone and sandy gray shale.... & $30-60$ \\
\hline Triassic or Permian.... & Chugwater formation & $\begin{array}{l}\text { Red sandy shale and fine-grained sandstone, } \\
\text { and beds of gypsum near base. }\end{array}$ & $80-1,000$ \\
\hline Carboniferous.......... & Casper formation.... & $\begin{array}{l}\text { Gray to red sandstone, gray to purple lime- } \\
\text { stone, and red shale. Gray to reddish brown } \\
\text { sandstone and conglomerate at base. }\end{array}$ & $800-1,000$ \\
\hline Pre-Cambrian.. & & Granite, gneiss, schist......... & \\
\hline
\end{tabular}

a This formation is not found near the Laramie Mountains but occurs extensively on the plains adjacent to Lodgepole Valley.

1 Darton, N. H., Blackwelder, Eliot, and Siebenthal, C. E., U'. S. Geol. Survey Geol. Atlas, JiramieSherman folio (No. 173), 1910. 
Below the Great Plains the formations older than the Tertiary lie nearly horizontal, but in a narrow belt along the edge of the mountains they are bent sharply upward and in some places overturned, faulted, or complexly warped. The Tertiary beds are nearly horizontal in this region, not only below the Great Plains; where they completely conceal the older formations, but also near the mountains, where to some extent they overlap the deformed and eroded edges of the older formations. In some parts of western Nebraska the Cretaceous strata younger than the Pierre shale are absent and the Tertiary beds rest on, this shale. ${ }^{1}$

As the Tertiary formations are important in connection with the ground water of this region, they will be briefly described.

The Chadron sandstone, which lies at the bottom of the Tertiary system, crops out near the Laramie Mountains, where it is a bed 20 to 40 feet thick overlapping the older formations. ${ }^{2}$ Eastward it passes under the Brule clay, but whether it is a continuous formation in the vicinity of Lodgepole Valley is not known.

The Brule clay is a moderately hard, compact, brittle, silty clay, prevailingly pale pinkish or flesh color. It has indistinct but regular bedding planes, and where it is weathered it is much jointed and broken into more or less cubical blocks. This is the formation that many of the drillers in Lodgepole Valley call "hardpan."

The Brule clay is at or near the surface over most of the Islay lowland between the Islay escarpment and the older formations that fringe the mountains (Pl. IV). It forms the lower part of this escarpment, outcropping to a height of about 70 feet in a locality southeast of the Van Tassell ranch, but it passes beneath the upland east of the escarpment and beneath the valley 2 or 3 miles east of the Heasman ranch. It again appears in the vicinity of Egbert, 45 miles farther east, where it is reached by the Egbert Railway well (p. 56) and comes to the surface at the base of the eastward facing escarpment (Pl. IV). It is at or near the surface over a considerable area of the Pinebluff lowland, from the Egbert escarpment to the Pinebluff escarpment. It crops out to a height of about 150 feet in the Pinebluff escarpment south of the village of Pinebluff but passes beneath the upland plain east of this escarpment. This formation apparently underlies the valley at no great depth throughout Nebraska, a distance of over 90 miles, and it is exposed at many places in the lower parts of the valley walls.

As the base of the Brule clay is not exposed except near the mountains and has rarely been reached in drilling in this region, the total thickness of the formation is not definitely known. Thicknesses of

Darton; N. H., Preliminary report on the geology and water resources of Nebraska west of the one hundred and third meridian: U. S. Geol. Survey Prof. Paper 17, pl. 11, 1903.

2 Darton, N. H., Blackwelder, Eliot, and Siebenthal, C. E., U. S. Geol. Survey Geol. Atlas, LaramieSherman folio (No. 173), p. 10, 1910. 


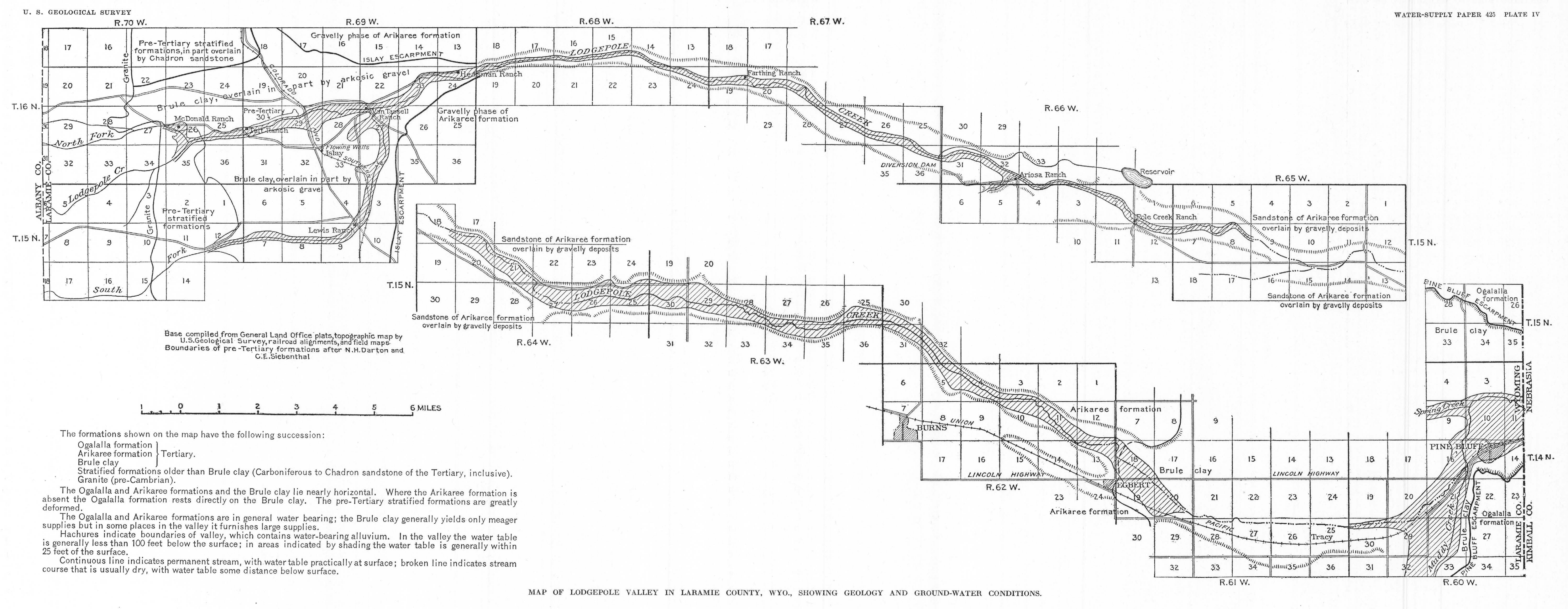


250 to more than 600 feet have been observed by Darton ${ }^{1}$ in adjacent parts of Nebraska and Wyoming. In a well 400 feet deep at Julesburg, Colo., 160 feet of "yellow clay," which is probably Brule clay, was found below the alluvial gravels. Below this clay there was a few inches of sand, below which blue shale-probably a Cretaceous formation-was penetrated 200 feet.

The Arikaree formation consists mainly of soft, fine-grained, light gray sandstone containing numerous large concretions that are very characteristic. It appears in typical character in the Egbert escarpment and for some miles west of Egbert, outcropping in the valley walls at least as far as the middle of T. 15 N., R. 64 W., and in tributary ravines a few miles west of Burns (Pl. IV). It is penetrated by many wells in the valley and on the upland from the vicinity of Egbert to the vicinity of the Pole Creek ranch. It is generally mantled by gravelly deposits, which west of the Pole Creek ranch form the entire valley wall and completely conceal the typical sandstone of the Arikaree formation. The Arikaree formation is not seen in the Pinebluff escarpment, nor at any point farther east near Lodgepole Valley. It is not found in typical character in the Islay escarpment, but the gravelly beds overlying the Brule clay are believed by Darton ${ }^{3}$ to represent a coarse phase of the Arikaree. The fine-grained concretionary sandstone appears to be merely a lens between the Brule clay and overlying gravelly deposits.

The Ogalalla formation, which lies on the Brule or the Arikaree, consists of irregular beds of poorly assorted clayey, sandy, and gravelly materials, and much calcareous cement. The less cemented parts are pinkish, but the calcareous beds are more nearly white or cream-colored. This formation underlies extensive areas of the Great Plains. It is exposed in the upper 100 feet of the Pinebluff escarpment and in the upper parts of the valley walls generally from Pinebluff nearly to the lower end of the valley. In the entire region adjacent to Lodgepole Valley east of Pinebluff, so far as known, the Ogalalla formation underlies the upland plain and rests on the Brule clay.

In the Islay escarpment southeast of the Van Tassel ranch the Brule clay is overlain by 70 feet of clean arkosic conglomerate, above which is about 40 feet of cemented gravelly beds, which resemble somewhat the Ogalalla formation but which are believed by Darton to be for the most part a gravelly phase of the Arikaree. Three miles below the Heasman ranch the entire valley wall, 250 feet high, appears to

\footnotetext{
1 Darton, N. H., Preliminary report on the geology and water resources of Nebraska west of the one hundred and third meridian: U. S. Geol. Survey Prof. Paper 17, pp: 37-40, 1903; and Darton, N. H., Blackwelder, Eliot, and Siebenthal, C. E., U. S. Geol. Survey Geol. Atlas, Laramie-Sherman folio (No. 173 ), 1910.

2 An excellent description of this sandstone is given in Prof. Paper 17, pp. 25-29.

${ }^{8}$ Darton, N. H., Blackwelder, Eliot, and Siebenthal, C. E., U. S. Geol. Survey Geol. Atlas, I aramieSherman folio (No. 173), p. 11, 1910.
} 
consist of poorly assorted gravelly and clayey beds-evidently coarse outwash from the near-by mountains. These gravelly deposits extend eastward indefinitely but become much thinner in the vicinity of Burns and Egbert, where at many places they rest with sharp con trast on the very different beds of the typical Arikaree formation.

The valley is underlain through almost its entire length by recent alluvium, which generally includes considerable coarse, clean gravel. The deposit is, however, not thick, the well records indicating 10 to 15 feet at Pinebluff; 35 to 50 feet or more at Bushnell, Kimball, and Potter; 25 feet at Sidney; 20 to 30 feet at Zunol; 15 to 20 feet at Lodgepole; 35 feet at Chappell; and 40 feet at Julesburg. On much of the Islay lowland and the lowland between Egbert and Pinebluff the alluvium is absent or very thin. At some places below Egbert the creek has cut into the Brule clay.

A gravelly deposit that is probably intermediate in age between the Ogalalla formation and the recent alluvium covers a considerable area of lowland west of Islay, and gravels of intermediate age are found also on the terraces throughout the valley.

\section{PRECIPITATION.}

The following table, compiled from the published records of the United States Weather Bureau to 1909, shows that Lodgepole Valley is in the semiarid region, in which dry farming is practiced but in which production can be greatly increased by irrigation. The precipitation is greatest in spring and summer and least in fall and winter. It is no doubt somewhat greater in the mountains than on the plains, but on the plains it does not decrease very much from east to west. The precipitation in the valley is probably not much different from that on the adjacent upland.

Average monthly precipitation, in inches, at points in or near Lodgepole Valley.

[Compiled from the published records of the U.S. Weather Bureau to 1909.]

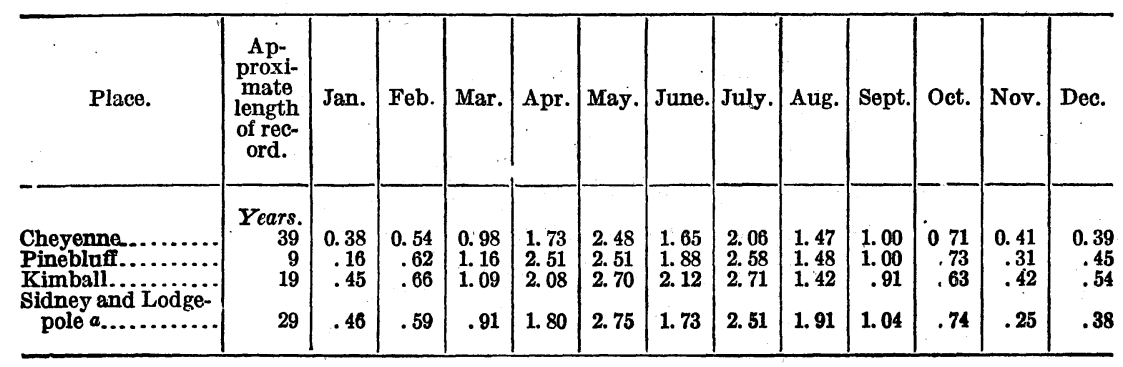

- Lodgepole since 1894. 
Lowest, highest, and average annual precipitation at points in or near Lodgepole Valley.

\begin{tabular}{|c|c|c|c|c|c|}
\hline$\therefore$ & Place. & $\begin{array}{l}\text { Number } \\
\text { of com- } \\
\text { plete } \\
\text { years } \\
\text { covered } \\
\text { by the } \\
\text { record. }\end{array}$ & Lowest. & Highest. & Average. \\
\hline $\begin{array}{l}\text { Cheyenne.. } \\
\text { Pinebluff.. } \\
\text { Kimball... } \\
\text { Sidney.... }\end{array}$ & 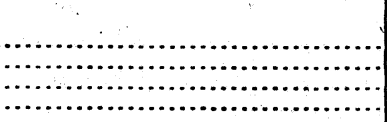 & $\begin{array}{r}37 \\
8 \\
15 \\
20\end{array}$ & $\begin{array}{r}\text { Inches. } \\
5.04 \\
10.90 \\
11.13 \\
7.70\end{array}$ & $\begin{array}{r}\text { Inches. } \\
22.68 \\
26.24 \\
25.59 \\
26.92\end{array}$ & $\begin{array}{r}\text { Inches. } \\
13.80 \\
15.29 \\
15.74 \\
15.07\end{array}$ \\
\hline
\end{tabular}

\section{SURFACE WATERS.}

The north and south forks of Lodgepole Creek head in a number of branches in the Laramie Mountains and unite on the Islay lowland at the Van Tassell ranch. Thence the creek leads to South Platte River, into which it discharges about 5 miles above Julesburg, Colo. The length of the creek from its sources to its mouth is about 175 miles if measured along the main trend of the valley but much more if measured along its intricately meandering channel. In its long course through the Great Plains it receives storm waters from innumerable gullies and the underflow from numerous tributary valleys and no doubt from the adjacent uplands, but only a few of its tributaries carry a perennial flow of surface water, and these are small.

Lodgepole Creek does not persistently decrease in volume downstream, like most desert streams, nor does it persistently increase, like most streams in humid regions, but its flow increases and decreases in alternating reaches and in three reaches its channel is normally dry. No gaging station has been maintained on Lodgepole Creek, but current-meter measurements have frequently been made at many places by the United States Geological Survey and the State engineer of Nebraska, the results of which are given in the table on page 46 . At the time the valley was examined, in September, 1915, the flow of the creek was measured or estimated at the points indicated below. The differences in flow were due to some extent to diversions that were not specifically noted.

About half a mile above the Heasman ranch, where the creek leaves the Islay lowland and enters the gorgelike valley, its flow, as measured with a current meter, was about $7 \frac{1}{2}$ second-feet, most of the water being contributed by branches that head in the mountains and little gain or loss being made on the Islay lowland. From this point to the diversion dam, about 14 miles downstream, in the NE. $\frac{1}{4}$ sec. 36, T. 16 N., R. 67 W. (see Pl. IV), the flow appeared to decrease slightly. At this dam the surface water and presumably nearly all the underflow was diverted, the total being probably somewhat less than the flow above the Heasman ranch. For a short distance below 
the dam the channel was dry; but at the Ariosa and Pole Creek ranches the flow was fully 1 second-foot. A few miles below the Pole Creek ranch, however, the stream disappeared and the channel was dry for a distance of nearly 10 miles.

From a springy area near the west margin of sec. 26, T. $15 \mathrm{~N}$, R. 64 W., to a point north of Egbert, in sec. 13, T. 14 N., R. 62 W., a distance of about 15 miles, there was a continuous stream, which, however, probably nowhere carried more than 1 or 2 second-feet. From Egbert to its junction with Muddy Creek, just southwest of Pinebluff, a distance of a little more than 10 miles, Lodgepole Creek was entirely dry, and the fact that its channel in this stretch is cut through the alluvium into the Brule clay indicates that there is but little underflow here.

At Pinebluff, a short distance west of the Wyoming-Nebraska State line, Lodgepole Creek is replenished by two tributaries, both of which rise on the Great Plains. In September, 1915, Muddy Creek, the south-side tributary, discharged approximately 1 second-foot, and Spring Creek, the north-side tributary, discharged approximately 3 second-feet into the channel of Lodgepole Creek. Considerable underflow along these streams also entered Lodgepole Creek, so that 2 miles below the mouth of Spring Creek, at the road half a mile east of the State line, the measured flow of Lodgepole Creek was about 6 second-feet.

In September, 1915, Lodgepole Creek contained flowing water from its junction with Muddy Creek nearly to Dix, a distance of about 33 miles. It was intercepted by the Kimball reservoir, in T. $15 \mathrm{~N}$., R. $57 \mathrm{~W}$., but some water was escaping under the dam of this reservoir. Half a mile below the dam its flow was fully 2 second-feet, and at Kimball it had increased to more than 6 second-feet, as measured with a current meter. Farther downstream, at the west margin of sec. 25 , T. 15 N., R. 55 W., its flow decreased to about 3 second-feet, and at the west margin of sec. 27 , T. 15 N., R. 54 W., to about 1 second-foot, and before reaching the road that extends northward from Dix the channel became entirely dry.

The channel was dry from the vicinity of Dix to a point below Potter, a distance of about 12 miles, but this part of the valley is underlain by gravel and no doubt carries considerable underflow.

The stream reappeared in sec. 9, T. 14 R., R. 52 W., and thence flowed without interruption so far as observed at least to the Colorado State line. It was reported that near its mouth the creek again sinks, at least in some seasons, but this report was not verified. About midway between the east and west margins of sec. 2, T. $14 \mathrm{~N}$., R. 52 W., 2 or 3 miles below the point where the creek reappeared, its flow was somewhat more than 4 second-feet, as measured with a current meter, and at Sidney it was about 6 second-feet. Below 
Sidney it showed some irregularities, but in the vicinity of Lodgepole it was enlarged to perhaps 10 second-feet by contributions from several springs and from the underflow of tributaries entering the valley from both sides. Farther downstream the flow decreased, and a float measurement made about a mile west of Chappell indicated that it was about 5 second-feet. Still farther downstream, however, it increased considerably, and in sec. $12, T .12$ N., R. 45 W., not far from the Colorado State line, a float measurement indicated that it was about 15 second-feet. Apparently the amount of underflow also increased considerably in the lower part of the valley. According to older reports the creek is sometimes dry in the lower part of T. 14 N., R. $51 \mathrm{~W}$., largely because of the diversion of water for irrigation, ${ }^{b}$ and near Colton, where the water sinks. ${ }^{a}$ The data given in the following table show that the creek is sometimes dry or very small at other places, but these minor fluctuations are in large part the result of irrigation:

Miscellaneous measurements of Lodgepole Creek, Wyo.-Nebr.c

\begin{tabular}{|c|c|c|}
\hline Locality. & Date. & $\begin{array}{l}\text { Flow, in } \\
\text { second- } \\
\text { feet. }\end{array}$ \\
\hline 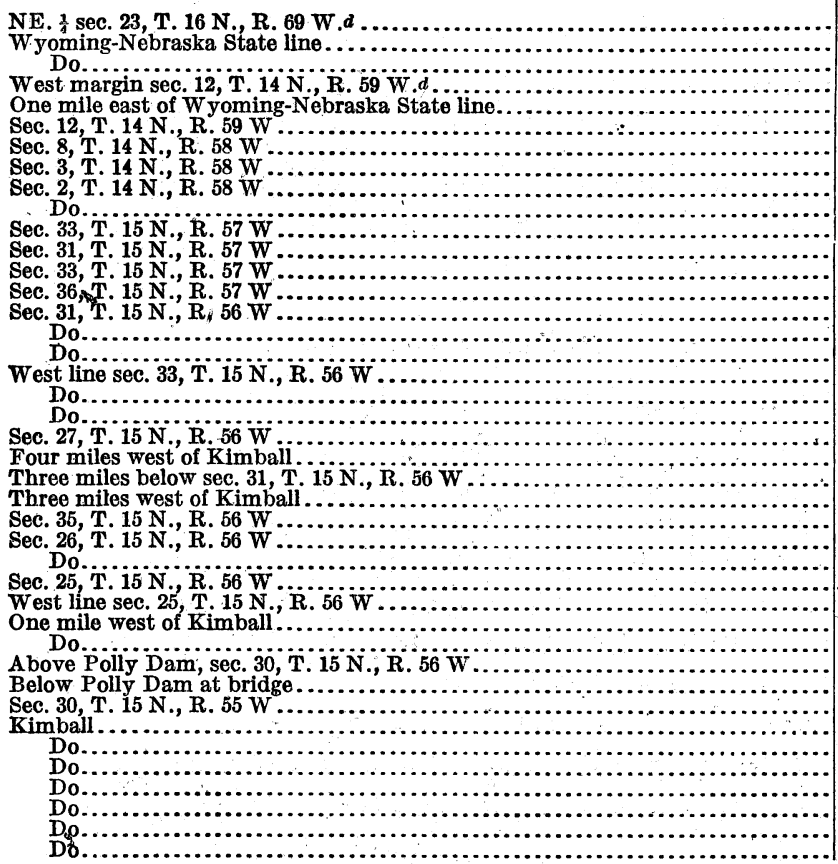 & 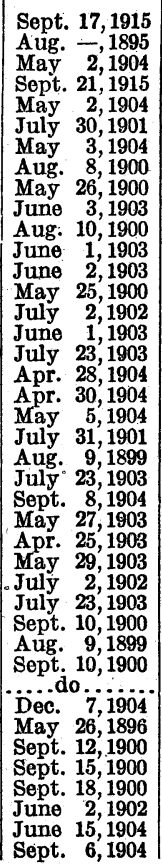 & $\begin{array}{c}7.45 \\
3.50 \\
4.30 \\
6.09 \\
4.60 \\
2.90 \\
34.50 \\
6.23 \\
9.23 \\
10.1 \\
12.34 \\
15.8 \\
12.8 \\
4.75 \\
10.5 \\
12.5 \\
.5 \\
14.4 \\
12.4 \\
48.2 \\
6.2 \\
7.43 \\
7.5 \\
8.6 \\
31.3 \\
16.6 \\
31.0 \\
7.5 \\
7.4 \\
1.29 \\
2.41 \\
2.44 \\
1.13 \\
25.6 \\
4.5 \\
4.92 \\
1.14 \\
4.3 \\
5.6 \\
2.1 \\
13.4\end{array}$ \\
\hline
\end{tabular}

a Dartón, N. H., Preliminary report on the ge-logy and water resources of Nebraska west of the one hundred and third meridian: U. S. Geol. Suri ey Nineteenth Ann. Rept., pt. 4, p. 770, 1898 .

b Price, D. D., Nebraska Bòad of Irrigation, Highways, and Drainage Tenth Bienn. Rept., p. 36, 1914.

$c$ See Hoyt, J. C., and Wood, B. D., Index to the hydrographic progress reports of the United States Geological Survey, 1888 to 1903, p. 127, 1905; and Price, D. D., Hydrographic report of Nebraska, 1914, pp. 333-335.

d Measurements by O. E. Meinzer.

$74351^{\circ}-19$-wsP $425-4$ 
Miscellaneous meusurements of Lodgepole Creek, Wyo.-Nebr.-Continued.

\begin{tabular}{|c|c|c|}
\hline Locality. & Date. & $\begin{array}{l}\text { Flow, in } \\
\text { second- } \\
\text { feot. }\end{array}$ \\
\hline 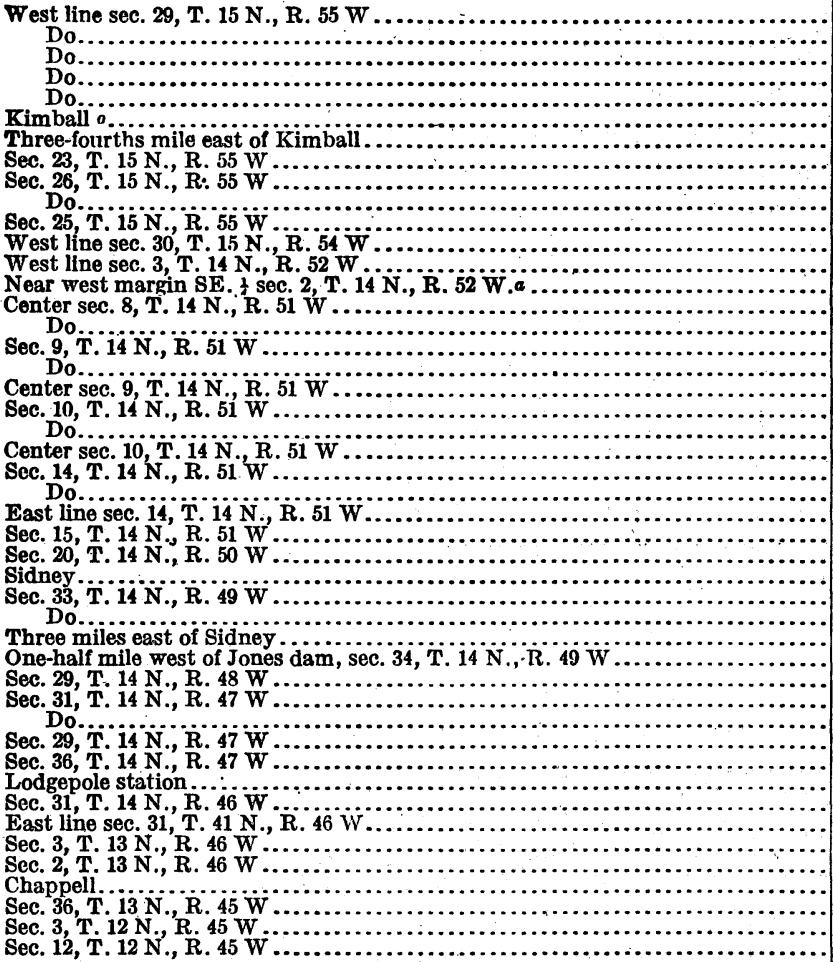 & 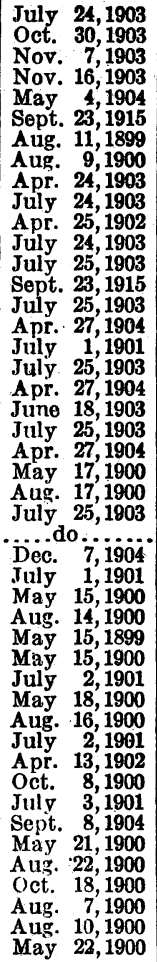 & $\begin{array}{c}6.6 \\
15.5 \\
21.6 \\
20.4 \\
20.5 \\
6.2 \\
2.09 \\
6.34 \\
12.64 \\
4.6 \\
12.0 \\
.0 \\
3.2 \\
4.20 \\
3.5 \\
8.62 \\
5.6 \\
3.8 \\
6.62 \\
15.4 \\
3.8 \\
7.25 \\
2.34 \\
2.35 \\
.0 \\
2.9 \\
4.4 \\
6.7 \\
3.86 \\
6.42 \\
10.95 \\
6.26 \\
4.0 \\
2.6 \\
2.5 \\
2.2 \\
4.0 \\
2.12 \\
3.4 \\
3.3 \\
2.26 \\
2.85 \\
3.11 \\
3.12 \\
1.34 \\
1.33\end{array}$ \\
\hline
\end{tabular}

a Measurements by 0 . E. Meinzer.

According to State Engineer Price, Lodgepole Creek is noted for its early spring floods, due to melting snows and heavy spring rains. The largest flow that has been measured was 48 second-feet, but Mr. Price states that during short flood stages the flow greatly exceeds this amount. ${ }^{1}$ In the upper part of its course, where it receives its water from the mountains, the creek fluctuates greatly in volume, but these fluctuations have little effect on the flow in the lower parts of the stream. Near Egbert the flood waters sink rapidly into the gravels, and the freshets rarely get far except in winter, when the ground is frozen. At no time during the summer of 1915 did the water flow across the road leading northward from Egbert. It is reported that at Potter no water flows in the creek bed even during heavy rains, and the infrequency of floods is indicated by the fact that there is a well on the bed of the creek and a house hardly 5 feet higher.' 
WATER IN ALLUVIAL GRAVEL AND SULJACENT BEDS.

\section{OCCURRENCE.}

The alluvial gravel in Lodgepole Valley and the porous or cavernous parts of the formations immediately under the gravel form a reservoir in which is stored a part of the water that falls as rain or snow in the valley. The alluvial gravel is generally clean and coarse and therefore can hold much water and yield it freely, as is shown by records of such wells as the city wells of Kimball, Sidney, and Chappell, the railroad well at Chappell, and the irrigation well of Mr. Gus Forsling. (See pp. 56-61.) Its total capacity as a reservoir is, however, limited by the shallowness of the alluvial deposit, especially in the Islay and Pinebluff lowlands.

In most of the valley below Egbert the alluvial gravel is underlain by Brule clay, locally known as "hardpan." In general this formation is a poor water bearer, but at many places where it underlies the gravel it appears to yield water very freely, as is indicated by the records of the city well at Pinebluff, the railroad wells at Egbert and Pinebluff, the Campbell irrigation well, and other wells mentioned on pages 56-61. This capacity to yield water freely appears to be due to joints or other crevices in the clay where it lies belo. $v$ the alluvial gravel. The storage capacity of these crevices is, however, probably not great, so that the clay is dependent on the overlying gravel for reserve supplies. Where the gravel deposit is very thin, as in the Pinebluff lowland and along the margins of the valley generally, the Brule clay is not always a reliable source of water, and some wells that end in it yield only small amounts.

Between Egbert and the Pole Creek ranch the alluvial gravel is underlain by sandstone of the Arikaree formation, which contains much water but which, on account of its fine grain and its incoherence, does not part with its water so freely as the gravel or the vesicular clay. By using coarse screens, cleaning out the wells thoroughly, and inserting gravel if necessary, large supplies could probably be obtained from this formation.

The sections of the city and railroad wells at Potter suggest that the water-bearing beds which there lie below the alluvium may belong to the Ogalalla formation. Both these wells yield the large quantities of water that would be expected from wells that end in gravel beds of the Ogalalla formation.

\section{THE WATER TABIE.}

The underground reservoir formed by the gravel, sand, and vesicular clay is filled with water about to the level at which the water stands in wells. The water table, or surface below which the deposits are saturated, is, of course, not entirely level but slopes downstream with approximately the same grade as the valley floor, and also no 
doubt generally slopes from the margins of the valley toward the stream channel. The average grade of the water table is about 27.5 feet per mile from the junction of the north and south forks of Lodgepole Creek to the Wyoming-Nebraska State line, 16 feet per mile in Kimball County, 15 feet per mile in Cheyenne County, and 15 feet per mile in Deuel County.

The depth to the water table is one of the most important factors determining the lift and therefore the cost of pumping. The water table comes practically to the surface along those parts of Lodgepole Creek in which water is flowing, as is indicated by springs, wet ground, and salt grass. It generally passes beneath the surface on each side of the creek and also in the reaches where the creek is dry.

According to the rapid survey made in September, 1915, the floor of Lodgepole Valley, including the terraces, covers about 150,000 acres. In about 60,000 acres of this area the depth to the water table is less than 25 feet, and in most of the rest it is less than 50 feet. The area in which the water table is less than 25 feet below the surface is distributed about as follows: Laramie County, 15,500 acres; Kimball County, 10,500 acres; Cheyenne County, 23,500 acres; Deuel County, 10,500 acres.

In the dry reach below the Pole Creek ranch the depth to the water table increases for several miles down the valley and then gradually decreases. On September 14, 1915, the water in a well in the NE. $\frac{1}{4}$ sec. 20 , T. 15 N., R. 64 W., stood 18 feet below the surface, or about 8 feet below the level of the stream channel, and that in a well in the SE. $\frac{1}{4}$ sec. 26, T. 15 N., R. 64 W., stood 17 feet below the surface, or about 7 feet below the level of the dry channel. Along the channel in sec. 26 there are trees that evidently reach ground water, and at the east margin of the section the ground water reappears in springs.

In September, 1915, the second dry reach began in sec. 13, T. 14 N., R. 62 W., and it was reported that in only one summer in recent years has the stream reached the east margin of this section except during occasional freshets. In a dug well, 26 feet deep, in the NW. $\frac{1}{4}$ sec. 18 , T. 14 N., R. 61 W., the water stood 23 feet below the surface, or about 13 feet below the dry channel. In a dug well near the northeast corner of sec. 30, T. 14 N., R. 61 W., only slightly above the valley floor, the water stood 25 feet below the surface. In a drilled well in the SW. $\frac{1}{4}$ sec. 10 , in the same township, the water stood 46 feet below the surface. In a drilled well in the NE. $\frac{1}{4}$ sec. 21 the water stood 55 feet below the surface, or about 30 feet below the level of the dry channel due south. In a well near the east margin of sec. 26 the water appeared to be about 30 feet below the dry channel. Down the valley from Tracy siding the ground water apparently comes nearer the surface; in a well in the NE. $\frac{1}{4}$ sec. 32 , T. 14 N., R. 60 W., in Septemoer, 1915, it was only 9.5 feet. below 
the surface, and along the valley of Muddy Creek it appeared at the surface.

The third dry reach began east of the east margin of sec. $29, \mathrm{~T}$. $15 \mathrm{~N}$., R. $54 \mathrm{~W}$. In a drilled well in the NW. $\frac{1}{4}$ sec. 26 , the water stood 35 feet below the surface, or about 23 feet below the dry channel. In a well in the SW. $\frac{1}{4}$ sec. 30 , T. 15 N., R. 53 W., the water stood 17 feet below the surface, or only about 11 feet below the dry channel. In a well near the southwest corner of sec. 30 , about 30 feet above the dry channel, the depth to water was reported to be 38 feet, and on still higher ground, about a mile farther south, the depth to water was reported to be about 100 feet. In a drilled well in the NW. $\frac{1}{4}$ sec. 36, T. 15 N., R. 54 W., on the south side of the road about 2 feet below the level of the railroad, the depth to water was - 57 feet. In a well in the NW. $\frac{1}{4}$ sec. 2 , T. 14 N., R. 53 W., about 55 feet above the dry channel due north, the depth to the water was reported to be about 100 feet, or 45 feet below the level of the dry channel. The water in a well near the middle of the east margin of sec. 2 , on ground 15 or 20 feet lower, was reported to be 60 feet below the surface, and in a well a mile farther east 49 feet below the surface. In a well drilled in the NE. $\frac{1}{4}$ sec. 1 the water stood 32 feet below the surface, or fully 20 feet below the level of the dry channel and 40 feet below the first terrace. A well in the NW. $\frac{1}{4}$ sec. 6, T. 14 N., R. 52 W., was dry at a level 18 feet below the stream channel. Just west of Potter, where the railroad crosses the creek, the water in an excavation made a few years ago was found to be 22 feet below the level of the dry channel. In the city well at Potter the water was 33.5 feet below the surface, or about 12 feet below the level of the stream channel due south. In a well 30 feet deep in the stream channel due south of the Potter city well the depth to water was said to be 14 feet. A little more than a mile farther down the valley the ground water comes to the surface.

The sinking of the water table to considerable depths below the surface and the consequent drying up of the stream in several parts of the valley may be due to irregularities in the grade of either the valley or the water table. Irregularities in the grade of the water table could be produced by differences in the quantity of water contributed to the underground supply or in the porosity of the alluvium. The water table will be high where the inflow is great and also where the ground water is more or less impounded by relatively impervious alluvium. Difference in inflow is certainly one of the causes of variation in level, but the interrelations of the various factors can not be determined until an accurate profile of the stream channel is made.

On account of the slope of the water table the ground water moves constantly but slowly downstream. The rate of movement depends 
on the porosity of the material and on the grade of the water table. According to underflow measurements that have been made by the United States Geological Survey, the average rate of movement in the general direction of the valley is 8 feet per 24 hours in the valley of Arkansas River near Garden City, Kans., 17 feet in the valley of the South Fork of Republican River near St. Francis, Kans., ${ }^{2}$ and 6.4 feet in the valley of the South Platte near Ogalalla, Nebr. ${ }^{3}$ The slope of the water table at the localities where the measurements were made amounted to 7.5 feet per mile in the Arkansas Valley and 10.7 feet in the valley of the South Fork of the Republican. The alluvia] gravels in Lodgepole Valley probably conduct water as freely as the similar gravels in the valleys where the underflow measurements were made and the grade of the water table is somewhat steeper (p. 48). Where the ground-water supply is replenished to such an extent that the underground reservoir overflows, the surplus water is carried away as a surface stream at a rate much more rapid than that of the underflow.

\section{SOURCE AND DISPOSAI.}

A rough balance between intake and discharge of ground water is maintained naturally in Lodgepole Valley from year to year. The underground supply in the valley is replenished by (1) downward percolation of water that falls directly on the valley as rain or snow: (2) downward percolation of water that reaches the valley in permanent streams or in freshets; (3) underflow from the alluvial deposits of tributary valleys; and (4) percolation from the waterbearing members of the Ogalalla, Arikaree, and other formations that underlie the uplands adjacent to the valley. Practically all this water is derived from the precipitation on the drainage basin of Lodgepole Creek. The underground supply is diminished by (1) evaporation where the water table is near the surface, (2) transpiration of plants, (3) seepage into the creek bed, and (4) underflow into the South Platte Valley. The water that seeps into the creek bed either returns to the atmosphere by evaporation and transpiration, flows into the South Platte, or percolates back into the underground reservoir. Considerable surface water that reaches the valley flows through to the South Platte because the underground reservoir of the valley is full or so nearly full that but little water can percolate into it.

If ground water is pumped in large quantities, the water table will be somewhat lowered. As a result, there will be smaller loss by

\footnotetext{
1 Slichter, C. S., The underflow in Arkansas Valleyin western Kansas: U. S. Geol. Survey Water-Supply Paper 153, p. 5, 1906.

2 Wolff, H. C., The utilization of the underflow near St. Francis, Kans.: U. S. Geol. Survey WaterSupply Paper 258, p. 119, 1911.

3 Slichter, C. S., and Wolff, H. C., The underflow or the South Platte Valley: U. S. Geol. Survey WaterSupply Paper 184, p. 11, 1906.
} 
evaporation, transpiration, and seepage into the creek, and greater replenishment from stream water that would otherwise reach the South Platte and from ground water on both sides of the valley. Thus a new balance will tend to become established between the intake and the withdrawal, including the withdrawal by pumping. If the pumpage in any section of the valley is increased beyond the limits of possible adjustment, there will, of course, be progressive depletion of the supply. The total quantity of water utilized, and hence the total acreage of land irrigated, can be increased by pumping from wells, because pumping will eliminate a part of the natural waste that now occurs through evaporation, transpiration from plants of little or no value, and escape of surface water; but there is probably no practicable way of effecting this increase in total recovery without reducing the flow of the creek.

The total appropriations for irrigation from Lodgepole Creek amount to nearly 400 second-feet, ${ }^{1}$ but the natural flow of the creek at any point is only a fraction of the amount appropriated. If the water of the creek is diverted at some point, other water will seep into the channel below the point of diversion, and not far below there is likely to be a considerable stream. Obviously, the channel of the creek where it is not normally dry has somewhat the function of a well. It extends below the ground-water level, and hence when its water is removed the supply is replenished from the underground reservoir. Thus the underground reservoir is already utilized, water being artificially drawn from it in the irrigation season through the ditches that lead from the creek. Pumping from wells would, in a sense, be an extension of the same process and would result in a still more effective use of the underground reservoir. Pumping from wells extending to the subjacent formation-the second or lower water horizons-would interfere less with the stream flow than pumping from shallow wells. By bringing to the surface water that had been confined by an impervious bed pumping from the deeper wells might even raise the water table and add to the stream flow.

In order to make even an approximate estimate of the quantity of water that could be recovered by pumping from wells, it would be necessary to have much more information than is at present available in regard to the average annual discharge of Lodgepole Creek, the loss by evaporation and transpiration, and other factors that are involved.

According to official records of the States of Wyoming and Nebraska, the area irrigated from Lodgepole Creek and its tributaries amounted in 1912 to about 23,500 acres. $^{2}$ A large part of the water

1 Price, D. D., Nebraska State Board of Irrigation, Highways, and Drainage Tenth Bienn. Rept., p. 49, 1914. Jabelmann, Louise, Tabulation of adjusted rights in water division No.1, pp. 121-123, Wyoming State Board of Control, 1912.

2Price, D. D., op, cit., p. 117 Jabelmann, Louise, op. cit., pp. 121-123, 
applied in irrigation percolates back to the underground reservoir. If it is assumed that the net annual withdrawal of water for irrigation is 2 acre-feet per acre, and that 23,500 acres are irrigated, the total net withdrawal is 47,000 acre-feet a year, or less than 3 per cent of the precipitation on the drainage basin of Lodgepole Creek. If the deposits underlying Lodgepole Valley are assumed to have an available porosity of 20 per cent, this amount of water is stored in $1 \frac{1}{2}$ feet of depth of the underground reservoir. If, on these assumptions, the irrigated area were increased 20 per cent by pumping from wells, the average lowering of the water table caused by pumping during an irrigation season would not exceed 0.3 foot, and there would probably be almost complete recovery through recharge during the rest of the year. If the irrigated area were doubled the lowering during an irrigation season would be within $1 \frac{1}{2}$ feet, but it would probably be enough to interfere seriously with the stream flow. Moreover, there would probably not be complete recovery by recharge in unfavorable seasons and thus the lowering might progress from year to year. Of course, the more widely distributed are the areas irrigated with well water the greater will be the salvage and the less will be the average effect on the water table and on the stream flow. .

QUALITY.

The table on pages 54-55 gives two analyses of water from Lodgepole Creek and 20 analyses of waters from wells in or near Lodgepole Valley. Twelve of these analyses were made under contract for the United States Geological Survey by S. C. Dinsmore in connection with the present investigation, nine were made by the Union Pacific Railroad Co. under the direction of N. F. Harriman, chief chemist, and one was made by the Kennicott Water Softener Co. Three of the analyses (Nos. 13, 14, and 22) are of water from shallow wells that end in the alluvial gravel; seven (Nos. 8, 9, 11, 12, 17, 18, and 21) of water from the Brule clay, underlying the alluvium, with more or less admixture of water from the alluvium; two (Nos. 15 and 16) apparently from the Ogalalla formation underlying the alluvium; one (No. 4) from the upland gravel deposits above the sandstone of the Arikaree formation; two (Nos. 7 and 10) from the sandstone of the Arikaree formation; and one (No. 2) probably from the Fox Hills formation,

The water of the streams that flow from the granitic area of the mountain province (No. 1) is low in total solids and is of the calcium carbonate type. In passing over the outcropping sedimentary rocks the mineral content of the stream water appears, however, to be more than doubled in the course of a few miles, a large part of the addition evidently being from the gypsum beds of the Chugwater formation that outcrop at the edge of the mountains (see analysis No. 3). 
None of the ground waters that were analyzed differ to any great extent from the sample of stream water; and in view of their rather wide geographic distribution and the diversity of their geologic sources they are remarkably similar to each other in total dissolved solids and in the proportions of the various constituents. None of - them are highly mineralized, but all contain a moderate amount of dissolved mineral matter, the principal constituents being calcium and the bicarbonate radicle. They range in total solids from 212 to 501 parts per million, in calcium from 34 to 75 parts, in magnesium from 9.4 to 18 parts, in sodium and potassium from 1.9 to 65 parts, in bicarbonate from 130 to 371 parts, in sulphate from 12 to 70 parts, and in chloride from 2.6 to 20 parts.

The water from the Brule clay contains on an average somewhat more mineral matter than the rest. The largest content of total solids was found in sample No. 21, which was taken from the Brule clay at a depth of 90 feet, the water from higher horizons being shut out. Some of the upland wells that end in the Brule clay are said to yield poor water, but no analyses are available to substantiate this report. The analyses given in the table also seem to indicate a slight general increase in mineralization in the downstream direction.

So far as is shown by the analyses, the waters of this region are all satisfactory for irrigation, the content of sodium in none of them being high. They are also in general good for domestic uses except that their rather high content of calcium and magnesium renders them moderately hard. They deposit considerable soft scále in steam boilers but are used without serious trouble in the locomotives on the Union Pacific and other railroads and for steam making wherever required. At some points along the railroad, however, the water is treated at sof tening plants before it is used in locomotives. 
[Parts per million except as otherwise designated.]

\begin{tabular}{|c|c|c|c|c|c|c|c|c|c|}
\hline No. & Owner or name. & Location. & Well or creek. & $\begin{array}{l}\text { Depth } \\
\text { of well. }\end{array}$ & $\begin{array}{l}\text { Diam- } \\
\text { eter of } \\
\text { - well. }\end{array}$ & Water-bearing formation. & $\begin{array}{l}\text { Depth } \\
\text { to } \\
\text { water } \\
\text { level. }\end{array}$ & $\begin{array}{l}\text { Date sample } \\
\text { was collected. }\end{array}$ & Analyst. \\
\hline 1 & North Fork of & Near east marg & Creek.. & Feet. & $\begin{array}{l}\text { Ft. in. } \\
\text {......... }\end{array}$ & & $\begin{array}{l}\text { Ft.in. } \\
\text {.......... }\end{array}$ & Sept. 16,1915 & S. C. Dinsmore. \\
\hline 2 & Islay flowing wells... & $\begin{array}{l}\text { 27, T. } 16 \mathrm{~N} \text {., R. } 70 \mathrm{~W} \text {.; } \\
\text { at granite contact west } \\
\text { of Islay, Wyo. } \\
\text { Near railroad station, Is- }\end{array}$ & North flowing & $150-300$ & & Fox Hills formation (?).... & & .....do......... & Do. \\
\hline $\mathbf{3}$ & Lodgepole Creek at & $\begin{array}{l}\text { lay, Wyo. } \\
\text { Near east margin sec. } 23 \text {, }\end{array}$ & $\begin{array}{l}\text { well. } \\
\text { Creek........... }\end{array}$ & & & & & Sept. 17,1915 & Do. \\
\hline 4 & $\begin{array}{l}\text { Heasham ranch. } \\
\text { w. H. Thompson... }\end{array}$ & $\begin{array}{l}\text { T. } 16 \text { N., R. } 69 \text { W. } \\
\text { S. i sec. } 19, \text { T. } 16 \text { N.,.R. }\end{array}$ & Drilled well... & 260 & & Gravelly phase of Arikaree for- & 2510 & Sept. 15, 1915 & Do. \\
\hline 5 & Union Pacific R. R. & $\begin{array}{l}68 \mathrm{~W} \\
\text { Hillsdale, Wyo... }\end{array}$ & .....do. & 66 & 130 & mation. & & Jan. 25,1911 & Union Pacific R. R. \\
\hline $\begin{array}{l}6 \\
7\end{array}$ & 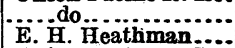 & $\begin{array}{l}\text { Durham, Wyo... } \\
\text { Burns, Wyo.... }\end{array}$ & & $\begin{array}{l}405 \\
134\end{array}$ & & Arikaree sandstone....................... & & Sept. 20,1915 & $\begin{array}{l}\text { Do. } \\
\text { s. C. Dinsmore. }\end{array}$ \\
\hline 8 & Union Pacific R. R. & Egbert, Wyo..... & Dug well........ & $\begin{array}{r}104 \\
35\end{array}$ & 160 & Brule clay underlying dry al- & $28 \%$ & Jan. 25,1911 & Union Pacific R. R. \\
\hline 9 & Bert Tucker... & Egbert, Wyo., NW. & .....do............ & 26 & $\ldots \ldots$. & Allurial gravel and underlying & 230 & Sept. 20,1915 & S. C. Dinsmore. \\
\hline 10 & Arnold Wilkowske... & Egbert, Wyo, SE & Drilled well... & 179 & & Arikaree sandstone................ & 1400 & .....do......... & Do. \\
\hline 11 & $\begin{array}{l}\text { Waterworks well } \\
\text { Union Pacific R. } \mathbf{R} .\end{array}$ & 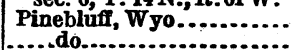 & 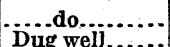 & $\begin{array}{l}76 \\
25\end{array}$ & $\begin{array}{rr}1 & 0 \\
14 & 6\end{array}$ & Brule clay below alluvial gravel. & $\begin{array}{ll}16 & 0 \\
12 & 0\end{array}$ & $\begin{array}{l}\text { Sept. 13,1915 } \\
\text { Sept. } 15,1913\end{array}$ & Do. \\
\hline $\begin{array}{l}13 \\
14\end{array}$ & 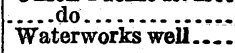 & Kushneil, Nebr.......... & Drilled rell... & $\begin{array}{l}37 \\
30\end{array}$ & $\begin{array}{rl}15 & 0 \\
5 & 2\end{array}$ & Auluvial gravel..................................................... & (n........ & $\begin{array}{l}\text { Jan. } 25,1911 \\
\text { Sept. 22,1915 }\end{array}$ & $\begin{array}{l}\text { Do. } \\
\text { s. C. Dinsmore. }\end{array}$ \\
\hline 15 & .....do . .............. & $\begin{array}{l}\text { ley north of city. } \\
\text { Potter, Nebr., near east }\end{array}$ & .....do...... & 72 & 126 & Ogalalla formation underlying & 336 & Sept. 23,1915 & Do. \\
\hline 16 & Union Pacific R. R. & Potter, Nebr............... & Dug well..... & 37 & 150 & Ogalalla formation $(?) \ldots \ldots \ldots \ldots$ & $(a)$ & Jan. 25, 1911 & Union Pacific R. R. \\
\hline 17 & Waterworks we & $\begin{array}{l}\text { Sidney, Nebr., on Main } \\
\text { Street, near n orth } \\
\text { edge of city. }\end{array}$ & .....do............ & $37 \pm$ & 150 & Alluvial graveland Brule clay.... & 200 & $\begin{array}{l}\text { Sept. } 5,1915 \\
\text {. }\end{array}$ & S. C. Dinsmore. \\
\hline 18 & $\begin{array}{r}\text { Union Pacific R. R.: } \\
\text { Well No.1........ } \\
\text { Well No. 2....... }\end{array}$ & $\begin{array}{l}\text { Sidney, Nebr.... } \\
\ldots . . . \text { do.................... }\end{array}$ & $\begin{array}{l}\text { (....do........... } \\
\ldots . . \text { do......... }\end{array}$ & $\begin{array}{l}33 \\
40\end{array}$ & $\begin{array}{ll}12 & 0 \\
16 & 0\end{array}$ & 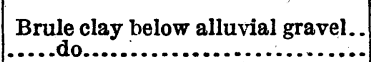 & ........ & 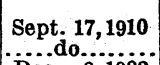 & Union Pacific R. R. \\
\hline $\begin{array}{l}19 \\
20\end{array}$ & \begin{tabular}{l} 
Union Pacific R. R.. \\
\hdashline$\ldots$ do
\end{tabular} & Iodgepole, $\mathrm{K}$ obr. & $\mathrm{Dug}$ and & $\dddot{56}$ & (n........ & ( & $\because \%$ & $\begin{array}{l}\text { Dec. } 9,1902 \\
\text { Nov. } 11,1913\end{array}$ & $\begin{array}{l}\text { Kennicott Water Softener Co. } \\
\text { Union Pacific R. R. }\end{array}$ \\
\hline $\begin{array}{l}21 \\
22\end{array}$ & $\begin{array}{l}\text { J. C. Johnson. } \\
\text { Union Pacifie R. R... }\end{array}$ & Chappeil, Nebr.................... & $\begin{array}{l}\text { Drilled well.... } \\
\text { D...do........... }\end{array}$ & $\begin{array}{l}90 \\
32\end{array}$ & $16 \cdots$ & $\begin{array}{l}\text { Brule clay below allurial gravel.. } \\
\text { Allu i } 1 \text { gra el............................ }\end{array}$ & 220 & $\begin{array}{l}\text { Sept. } 8,1915 \\
\text { Sept. } 17,1910\end{array}$ & $\begin{array}{l}\text { S. C. Dinsmore. } \\
\text { Union Pacific R. R. }\end{array}$ \\
\hline
\end{tabular}


a The following formulas, adapted by Dole (U. S. Geol. Survey Water-Supply Paper 375, pp. 160, 163-164) from those of Stabler (Water-Supply Paper 274) have been used for computing the total hardness $\left(\mathrm{H}\right.$ ) as $\mathrm{CaCO}_{3}$, the probable scale-forming ingredients (s), the probable foaming ingredients (f), and the tendency to cause corrosion (c):

$\mathrm{H}=2.5 \mathrm{Ca}+4.1 \mathrm{Mg}$. $\mathrm{s}=\mathrm{SiO}_{2}+2.95 \mathrm{Ca}+1.66 \mathrm{Mg}$. $\mathrm{f}=2.7$ ( $\mathrm{Na}+\mathrm{K}$ ). $\mathrm{c}$ - If $0.0828 \mathrm{Mg}-0.0336 \mathrm{CO}_{3}-0.0165 \mathrm{HCO}_{3}$ is positive the water is corrosive (C). If $0.0828 \mathrm{Mg}+0.0503$ the water (N. C.). If $0.0828 \mathrm{Mg}-0.0336 \mathrm{CO}_{3}-0.0165 \mathrm{HCO}_{3}$ is negative but

In these formulas $\mathrm{SiO}_{2}, \mathbf{C a}, \mathbf{M g}, \mathrm{Na}+\mathrm{K}_{2} \mathrm{CO}_{3}$, and $\mathrm{HCO}_{3}$ represent, respectively, the amounts in parts per million of silica, calcium, magnesium, sodium, potassium, carbonate, applying the formulas developed by Stabler for calculating the "alkali coefficient," which The alkali coefficients $(k)$ are computed by means of the following would yield

$\mathrm{k}=\frac{2,040}{\mathrm{Cl}}$ if $\mathrm{Na}-0.65 \mathrm{Cl}$ is zero or negative. $\mathrm{k}=\frac{6,620}{\mathrm{Na}+2.6 \mathrm{Cl}}$ if $\mathrm{Na}-0.65 \mathrm{Cl}$ is positive but not more than $0.48 \mathrm{SO}_{4}$. $\mathrm{k}=\frac{662}{\mathrm{Na}-0.32 \mathrm{Cl}-0.43 \mathrm{SO}}$ if $\mathrm{Na}-0.65 \mathrm{Cl}-0.48 \mathrm{SO} 4$ is positive. $b$ Calculated. honate.

c Reported by Union Pacific Railroad Co. in hypothetical combinations in grains per gallon; recalculated into ionic form in parts per million, and earbonate expressed as bicar- 


\section{DATA CONCERNING WELLS.}

IARAMIE COUNTY, WYO.

The few wells in the valley above Egbert are used only for domestic supply and for watering stock and their capacity has not been thoroughly tested. Some of the wells between Egbert and Pole Creek ranch are drilled and most of them end in sand of the Arikaree formation. The alluvial gravels would no doubt yield large supplies in much of this part of the valley, but they are not widely distributed and are generally not deep. The drilled wells in the vicinity of Islay are described on pages 63,64 .

The railroad well at Egbert is 35 or 40 feet deep, 16 feet in diameter, and is walled with stone laid in cement. It was sunk through dry gravel into "hardpan" which contains water-bearing crevices. The men in charge report that the well contains 7 feet of water, and that pumping at the rate of 150 gallons a minute lowers the water level very little.

The well that supplies the Pinebluff waterworks is 76 feet deep; the upper 16 feet is a dug pit, the rest a drilled hole with 12-inch perforated casing. The water level is about 16 feet below the surface. When the well was sunk there was, according to Mr. M. Ekstrom, the driller, only 4 inches of water-bearing gravel, below which the well penetrated Brule clay, the crevices of which furnish nearly all of the water. The pump is set 15 feet below the water level, and pumping 220 gallons a minute is reported by Mr. Ekstrom to cause a drawdown of 2.5 feet, indicating a yield of 90 gallons a minute for each foot of drawdown.

The railroad well at Pinebluff is about 25 feet deep and $14 \frac{1}{2}$ feet in diameter and, like the Egbert well, is walled with stone laid in cement. It was sunk through 8 feet of silty loam and a few feet of dry gravel, and ended in vesicular Brule clay; in which a satisfactory supply was obtained. The water level is about 12 feet below the surface, and, according to authentic information, is lowered 3 or 4 inches when the well is pumped at 150 gallons a minute and about 6 inches when it is pumped at 225 gallons a minute, indicating a capacity of about 450 gallons a minute for 1 foot of drawdown. When the well was being sunk it is reported to have been pumped simultaneously by a 5-inch and a 4-inch centrifugal pump.

The well of Mr. Ekstrom, in the SW. $\frac{1}{4}$ sec. 10, T. 14 N., R. 60 W., about 250 feet from the creek, is 13 feet deep, 20 feet in diameter, and is walled with concrete. It extends through gravel to the "hardpan." The water level is only 3 feet below the surface and the water is derived from the gravel. The well failed to supply 5-inch centrifugal pump which has a capacity of 735 gallons a minute but is supposed to yield about half this amount, or approximately 35 gallons for each foot of drawdown. 
A well dug by Mr. Ekstrom, 8 miles southwest of Pinebluff, only about 30 feet from the banks of Muddy Creek, to a depth of 20 feet, ends in "hardpan" but fails to supply a 4-inch centrifugal pump. Some of the wells between Pinebluff and Egbert yield supplies inadequate for domestic use or for stock.

KIMBAII COUNTY, NEBR.

The railroad well at Bushnell is 37 feet deep and 15 feet in diameter and is walled with stone laid in cement. It extends through gravel to the "hardpan." Pumping at the rate of 170 gallons a minute empties the well.

The railroad well at Kimball, which is on the second terrace, 60 feet above the level of the creek, is 93 feet deep and its water level is about 60 feet below the surface. A 16-foot hole was sunk to a depth of about 85 feet and was walled with stone laid in cement. This hole extended through dry gravel to a depth of 30 or 40 feet and thence through "hardpan" to the bottom, where a thin layer of water-bearing sand and gravel was found. The yield was unsatisfactory, and a hole was drilled in the bottom of this well to another water-bearing bed, which is said to consist of gravel. This increased the supply so much that pumping at the rate of 170 gallons a minute is reported not to lower the water level greatly, but pumping at 285 gallons a minute is reported to empty the well. The information regarding both the Bushnell and the Kimball railroad wells was furnished chiefly by Mr. J. R. McCart, in charge of the Union Pacific water supply between Durham, Wyo., and Julesburg, Colo.

The well that supplies the waterworks at Kimball is in the valley about one-fourth mile from the creek and about 15 feet above the creek level. It consists of a 5 -foot hole that extends to a depth of 15 feet, where water was encountered, and a 2-foot hole with perforated casing that extends down about 16 feet from the bottom of the 5 -foot hole. The entire well is in gravel. According to T. C. Thiele, who has charge of the pumping plant, the usual pumpage, as indicated by a meter, is 230 gallons a minute, and pumping at about this rate for 8 hours has produced a drawdown of only $1 \frac{1}{2}$ feet, indicating a capacity of about 150 gallons a minute for each foot of drawdown.

The well of Mr. Gus. Forsling is in the NE. $\frac{1}{4}$ sec. 34, T. $15 \mathrm{~N}$, R. 57 W., near the upper end of the Kimball reservoir. A 6-foot hole, walled with cement, goes to a depth of 18 or 20 feet, and a 14-inch suction pipe with a sereen 4 or 5 feet long extends below the bottom of the 6 -foot hole to about 31 feet below the surface. The entire well is in gravel. When tested on September 21, 1915, the water level was 15.45 feet below the bench mark, or about 15 feet below the surface, and pumping for one hour at an average rate of 
445 gallons a minute, according to two measurements made with a current meter, lowered the water level to 18.05 feet below the bench mark, or a distance of 2.60 feet. This test therefore indicated that the well has a capacity of about 170 gallons a minute for each foot of drawdown. Mr. Forsling reported that in a 12-hour run the water level was lowered about 4 feet. Data in regard to the pumping plant are given on pages $65-67$.

Wells sunk by Anton Linder and J. F. Bogle for irrigation of land not far east of Bushnell are supposed to yield satisfactory supplies but had not been severely tested at the time the valley was examined.

\section{CHEYENTE COUNTY, NEBR.}

The well that supplies the waterworks at Potter is 72 feet deep and is lined with 12-inch casing to a depth of 48 feet and 6-inch casing to the bottom, the casing being perforated with numerous holes onefourth inch in diameter. The section, as reported, is as follows: Water at 35 feet; water-bearing sand and gravel to 48 feet; "rock" to 50 feet; soft white clay to 63 feet; water-bearing sand and gravel to 72 feet, well ending in gravel. The depth to the water level September 23, 1915, was 34.65 feet below the platform, or 33.5 feet below the surface. The pumpage averages about 10,000 gallons a day. According to A. D. Irey, who is in charge of both village and railroad pumping plants, the well was tested at 120 gallons a minute, and this rate of pumping lowered the water level 3 feet, indicating a capacity of 40 gallons a minute for each foot of drawdown.

The railroad well at Potter is 37 feet deep, 15 feet in diameter, and is walled with stone laid in cement. It is reported to extend through gravel, "hardpan," and "rock." The water level is only a few feet above the bottom of the well. According to Mr. Irey, the well is pumped at about 125 gallons a minute, and this rate of pumping for 6 hours emptied the well in the fall of 1914 but not in the summer of 1915 .

The well that supplies the waterworks at Sidney yields more than any other well that was examined. It is about 37 feet deep, 15 feet in diameter, and is walled with stone. It extends through gravel to a depth of about 28 feet, below which it is in "hardpan." At the time the well was dug the lowest $1 \frac{1}{2}$ feet of gravel was saturated with water; on September 5, 1915, the water level was 26 feet below the surface. This well supplies about $28,000,000$ gallons a year, or an average of about 80,000 gallons a day. In a test made September 5,1915 , it was pumped for one hour at 710 gallons a minute, as measured by the installed meter, and the water level was lowered only 0.31 foot. Pumping for three.hours at about 650 gallons a minute is reported to produce a drawdown of about 8 inches. It is also reported that before any "hardpan" had been excavated the 
well was pumped at 1,100 gallons a minute without emptying it, all of the water presumably coming from the 18-inch layer of saturated gravel.

The Union Pacific Railroad Co. has two wells in Sidney that are somewhat similar to the city well. The new well is 40 feet deep, 16 feet in diameter, walled with stone laid in cement. It was sunk through dry gravel to the depth of 24 feet and through "hardpan" from this depth to the bottom, the first water being struck in crevices in the "hardpan" at a depth of about 30 feet. Mr. J. R. McCart reports that while the well was being sunk it was pumped 550 gallons a minute without exhausting the supply and that the well is usually pumped at about 350 gallons a minute. The old well is not so deep as the new one and yields less water.

Other wells in Sidney that yield considerable water are the Chicago, Burlington \& Quincy Railroad well, the schoolhouse well, and the well at the J. A. Reisdorff ice factory. The railroad well is a large dug hole reported to have only about 4 feet of water but to yield freely. The schoolhouse well has 7-inch casing and is said to be about 45 feet deep. It was pumped on September 3,1915 , at 35 gallons a minute, at which rate it is frequently pumped for 10 or 12 hours. The ice-factory well is a dug hole about 50 feet deep and is said to be a strong well, although it is pumped at a rate of only 10 or 12 gallons a minute.

The well that supplies the waterworks at Lodgepole is 100 feet deep, the upper 17 feet being a dug hole and the rest a drilled hole 14 inches in diameter. The first water was struck in gravel at the depth of 17 feet, and "hardpan" was reached at $17 \frac{1}{2}$ feet. Most of the supply is reported to have been found between the depths of 50 and 75 feet. The well is usually pumped at about 110 gallons a minute. This rate of pumping is reported to produce a drawdown, in some seasons of 5 or 6 feet, but at the time the well was examined, September 9, 1915, the drawdown was only about 1 foot.

The railroad well at Lodgepole is 56 feet deep. It consists of a dug hole about 30 feet deep and three 3 -inch drilled holes extending 26 feet downward from the bottom of the dug hole. As reported by Mr. J. J. Finnegan, who is in charge of the railroad water supply at this place and at Chappell, the well passed through water-bearing gravel between the depths of 7 and 11 feet and through hard clay from 11 feet to the bottom. The water level is about 8 feet below the surface. Pumping at the rate of 115 gallons a minute is reported by Mr. Finnegan to lower the water level about 2 feet in the first hour of pumping, after which there is no noticeable lowering even though the pump is run all day. In tests made September 9 and 10,1915, the drawdown was 1.35 feet after 20 minutes of pumping and 2.1 feet after 1 hour and 15 minutes, 2 hours, and 3 hours of 
pumping. These tests therefore indicated a capacity of about 55 gallons a minute for each foot of drawdown.

A few wells have been sunk in Cheyenne County to obtain water for irrigation, but none of them were being pumped in September, 1915. The dug well of Mr. Nels Olson, 2 miles west of Sidney, is 16 feet deep, and in September, 1915, the water level was 9.8 feet below the surface. This well is equipped with a pump rated at 750 gallons a minute, but no test of the yield was made. A shallow well, 8 feet in diameter, dug near the creek, on the Benjamin Glenn estate, in the SW. $\frac{1}{4}$ sec. $33, T$. 14 N., R. 49 W., was formerly provided with a rather large pumping plant to be used for irrigation, but it is now abandoned. The Campbell wells, on land now belonging to Mr. George Graves, in the NE. 1 sec. 35, T. 14 N., R. 47 W., were sunk to obtain a supply for irrigation but were not in use in 1915. There are five wells at intervals of 25 feet and a little less than 50 feet from the creek. As reported by Mr. J. C. Johnson, the driller: they were at first carried to depths of only 16 to 18 feet and were finished in gravel with 12-inch perforated casings. The depth to water level was about 7 feet. They yielded considerable water but did' not adequately supply the 6-inch centrifugal pump with which they were simultaneously pumped. Two of the wells were then extended as 8-inch uncased holes, through the "hardpan" to a total depth of 80 feet. Additional water struck in the "hardpan" rose to a level 2 or 3 feet above the original water level. These two wells, according to Mr. Johnson, supplied the pump. The discharge of the pumping plant is reported to have been 1,380 gallons a minute, but this report was not verified.

DEJEL COUNTY, NEBR.

The well that supplies the waterworks at Chappell is 4 feet in diameter and 34 feet deep and extends through gravel to the top of the clay. The water level is about 28 feet below the surface. According to Mr. R. H. Libby, who is in charge of the plant, the well is usually pumped at a rate of about 85 gallons a minute but has been tested at 200 gallons a minute. It supplies 5,000 to 30,000 gallons a day.

The railroad well at Chappell is 16 feet in diameter and 32 feet deep, and ends in gravel. The water level is reported to be about 22 feet below the surface. When measured by Mr. Finnegan, in 1916, pumping at the rate of 200 gallons a minute for several hours lowered the water level only $1 \frac{1}{2}$ feet.

The principal attempt in this part of the valley to recover ground water for irrigation was made by Mr. Skip McNew, who sank five 14-inch wells near the creek on sec. 12, T. $12 \mathrm{~N}$., R. $45 \mathrm{~W}$., and installed a 6-inch centrifugal pump. In 1915 the plant had been abandoned, but from such meager information as could be obtained 
it appears that the wells supplied the pump, which probably had a capacity of about 900 gallons a minute.

Near the Colorado State line Lodgepole Valley opens into the valley of the South Platte, which is wider, has a somewhat deeper deposit of alluvial gravel, and no doubt has a larger supply of ground water. At Julesburg ${ }_{\text {if }}$ Colo., just below the mouth of Lodgepole Valley, both city and railroad supplies are derived from the alluvial gravel, which is here about 40 feet thick.

The Julesburg waterworks are supplied by two wells, 14 feet apart, both of which, according to $\mathrm{Mr}$. C. H. Lent, superintendent of the city waterworks, are 40 feet deep and have 14-inch sheet-iron casings with perforations $1 \frac{1}{2}$ inches long and one-fourth inch wide. The water level is about 12 feet below the surface. It is reported that either of these wells will supply 750 gallons a minute with the suction pipe extending 15 feet below the water level. In a brief test made September 8, 1915, the two wells together supplied 750 gallons a minute, or somewhat more, with an average, drawdown of 3.33 feet, indicating a capacity for each well, when both are being pumped, of about 110 gallons a minute for each foot of drawdown.

The railroad supply at Julesburg is obtained from a well 16 feet deep and 12 feet in diameter, ending in gravel. The water level is 5 feet below the surface. In September, 1915, the well supplied 300 gallons a minute, but in dry seasons it has been emptied by pumping 200 gallons a minute. This information was furnished by Mr. McCart.

\section{WATER IN TERTIARY FORMATIONS.}

The Tertiary formations, named in their order from the top downward, are the Ogalalla formation, the Arikaree formation, the Brule clay, and the Chadron sandstone. They are described on pages $39-42$, and their water-bearing capacity where they lie below the alluvium is discussed on page 47.

The Ogalalla formation, which underlies large parts of the Great Plains, generally yields abundant supplies of good water from the irregular gravelly beds which it contains. This formation supplies most of the wells in the region adjacent to Lodgepole Valley east of Pinebluff, but in some places the base of the formation is so high above the valley that the water drains out of it and wells must be sunk into the underlying Brule clay.

The Arikaree formation consists largely of sandstone, the lower part of which is saturated with water that it yields rather freely to wells. Most of the drilled wells ending in this formation are cased to prevent caving, but some of the dug wells are left uncased. The sand causes some trouble by running into wells that are finished with $74351^{\circ}-19-$ wsP $425-5$ 
open ends or with large perforations in the casings and by clogging screens of finer mesh. So far as possible screens of fine mesh should be avoided, and the difficulty with sand should be overcome by thorough cleaning out and hard pumping at the time the wells are finished. If necessary gravel should be inserted to hold back the sand. As shown by analyses 7 and 10 (pp. 54-55) the water from the Arikaree formation contains only a moderate amount of mineral matter, which consists chiefly of silica, calcium, and bicarbonate, the two - last named rendering it somewhat hard. It is of good quality for irrigation. The sandstone of this formation is reached by wells on the upland and in the valley from the vicinity of the Pole Creek ranch to a point a little beyond Egbert. No traces of the formation were found farther east in or near Lodgepole Valley.

The wells on the uplands for some miles east of the Islay escarpment are supplied by water from gravelly beds that overlie the typical sandstone of the Arikaree formation. The water level here is rather deep, but the supplies are abundant and the water is good. A sample of the water was taken from the drilled well of $\mathrm{Mr}$. W. $\mathrm{H}$. Thompson in the S. $\frac{1}{2}$ sec. 19, T. 16 N., R. 68 W. (No. 4 in table on p. 54). This well is on the upland, 250 feet above the valley, in the region where the gravelly deposits extend down to the valley. The well is 260 feet deep and the depth to water level is said to be 251 feet. The owner reported that it passes through "clay and gravel" and ends in water-bearing "sand and gravel." The lowest 20 feet of casing is perforated to admit the water. The well yields freely and the water is good. East of the vicinity of the Pole Creek ranch the base of the gravelly deposits is generally above the water level and the wells penetrate the underlying sandstone.

The Brule clay is in general too dense to be a good water bearer and some wells drilled into it have been failures. In most places, however, it yields supplies that are adequate for domestic uses and for watering stock, and in parts of the valley it yields very freely. The water generally comes from the joints into which the formation readily breaks, but a few wells end in sand that appears to be interbedded with the clay. Most of the wells between Egbert and Pinebluff end in Brule clay and some of them are unsatisfactory. Many of the upland wells near Sidney and in other localities east of Pinebluff have also been drilled into the Brule clay and most of these yield some water. Although this formation yields water freely at many places in the valley, it becomes tighter near the margins of the valley, where wells have been drilled into it a few hundred feet without finding much water. The water from the Brule clay apparently contains somewhat more mineral matter than that from the overlying formations. It would deposit large amounts of scale in 
boilers but, so far as the analyses show, it is not generally too highly mineralized for domestic use or for irrigation. (See especially analysis No. 21, pp. 54-55.)

So few wells have been sunk to the base of the Brule clay that there is little information regarding the Chadron sandstone, which, near the mountains, crops out below this clay. In the few deep wells that have been drilled either this sandstone was absent or it did not supply much water. The flowing well at the city pumping plant in Julesburg, Colo., passed through "yellow shale" between the depths of 40 and 200 feet, and "blue shale" between the depths of 200 and 400 "feet, where the drilling was stopped. A 4-inch bed of sand between the two shale beds yielded a natural flow amounting to a fraction of 1 gallon a minute. If the "yellow shale" is the Brule clay, this thin bed of sand is at the horizon of the Chadron sandstone. Some of the other wells that reached sand after passing through the Brule clay may end in Chadron sandstone.

\section{WATER IN CRETACEOUS AND OLDER FORMATIONS.}

The formations in the general section shown on page 39 doubtless extend eastward beneath Lodgepole Valley, probably with some changes in character and thickness. The two notable facts regarding this section are that the Dakota sandstone, which in the vicinity of the Laramie Mountains is included in the Cloverly formation, is a widespread and very important artesian horizon and that the Pierre shale is a very thick and impervious formation which will produce little water and that of poor quality. Throughout most of its great thickness the Pierre shale consists of a dark plastic homogeneous shale. Above it and below the Tertiary system in this region there are alternating sandy and shaly beds (Fox Hills and other formations) which will yield some water, but which, so far as is now known, are not strong.water bearers. Below the Pierre shale-between this shale and the Dakota sandstone-lie the Niobrara limestone and the Benton shale, which also contain water-bearing members. Below the Dakota sandstone there are still other water-bearing formations, but they lie too far below the surface in this region to be considered as sources of water supply.

There are two flowing wells at Islay station and a 6-inch drilled. well on slightly lower ground in sec. 27 , in the same township, in which the water level in September, 1915, stood 3 feet below the surface, or 5.4 feet below the top of the casing. Definite information regarding the depths and sections of these wells could not be obtained, but according to N. H. Darton ${ }^{1}$ they are from 150 to 300 feet deep

1 Darton, N. H., Blackwelder, Eliot, and Siebenthal, C. E., U. S. Geol. Survey Geol. Atlas, LaramieSherman folio (No. 173), p. 17, 1910. 
and apparently derive their water from the Fox Hills sandstone. On September 16, 1915, the south well at Islay flowed about 2 gallons a minute and the north well about 10 gallons a minute. The water is of good quality, as is shown by analysis No. 2 (pp. 54-55). A well at Cheyenne, which is reported to have been 1,145 feet deep, passed through much sand and obtained a small flow but was not considered successful. ${ }^{1}$ A well on the farm of Mr. Frank Hand, about 6 miles south of Sidney, is said to have been sunk to a depth of about 1,000 feet and to have obtained only a small yield. If the well reached this depth it probably entered the Pierre shale. At Sterling, Colo., in the valley of the.South Platte, a well is reported to have been sunk to a depth of 600 feet, chiefly through blue shale. Artesian water that flowed 2 or 3 gallons a minute is reported to have been struck in a thin bed of sand at a depth of about 400 feet.

Too few wells have been sunk in this region to test adequately the water-bearing beds above the Pierre shale, and none of them were deep enough to reach the beds below the Pierre shale. There is some prospect of obtaining flowing wells by deep drilling in Lodgepole Valley from formations above or below the Pierre shale, but the prospect of obtaining adequate supplies at a cost low enough for irrigation by deep drilling must be regarded as poor. The formations above the Pierre shale could be tested by wells not more than 1,000 feet deep, but unless the formations are much thinner toward the east than where they outcrop, wells several thousand feet deep would be required to reach the Dakota sandstone.

\section{IRRIGATION WITH GROUND WATER.}

The problem of irrigation with well water in Lodgepole Valley relates chiefly to the cost and to the quantity of water available. Several wells have been sunk in the valley to obtain water for irrigation, but in 1915 only a few of these wells were used and some of them had been permanently abandoned. The supply has generally been large enough but the difficulty has been rather in the work and cost of pumping and applying the water.

The cost of pumping varies within wide limits. Success or failure depends largely on the care and the ability with which the plant is installed and operated. With good management, pumping for the irrigation of staple crops should at present be economically practicable in those parts of Lodgepole Valley where satisfactory wells can be obtained, where there is good soil to which to apply the water, and where the water table is within 25 feet of the surface. (See Pls.

1 Darton, N. H., Preliminary report on the geology and underground-water resources of the central Great Plains; U. S. Geol. Survey Prof. Paper 32, p. 366, 1905. 
IV, V, and VI.) Under favorable conditions pumping can probably be made profitable even where the depth to the water table is somewhat more than 25 feet. One of the chief causes of failure in a semiarid region, such as Lodgepole Valley, is that in the years of sufficient precipitation the pumping plants are neglected and are consequently out of repair when they are again needed.

The most practical type of pumping plant for Lodgepole Valley consists of one or more drilled wells, a centrifugal pump with a capacity of not less than about 1 second-foot and not more than several second-feet, and an internal-combustion engine adapted to the use of low-grade, inexpensive distillate, the water to be used in the vicinity of the pumping plant.

Where the water is obtained from gravel the wells can be dug by hand, but in general adequate supplies can be obtained at less cost by digging only to the water level and below this level sinking wells 8 to 14 inches in diameter and using casings that are abundantly perforated. In some localities it will be advisable to sink the wells into the "hardpan.". Where sufficient water is not obtained from one well, several wells can be sunk, 50 to 100 feet apart, and connected with the same pump.

Where the water table is not more than 25 feet below the surface, horizontal centrifugal pumps are commonly used, these pumps being installed just above the water level and connected with the engine by a belt that makes an angle of not more than $45^{\circ}$ with the horizontal. Vertical centrifugal pumps are generally submerged. They are adapted to use in wells in which the water level lies rather deep or fluctuates greatly.

A large central power plant with electric-transmission lines extending to the individual pumping units, such as have been installed near Garden City, Kans., and at Portales, N. Mex., would probably have some advantage in economy and convenience over small engines installed at the pumps, but the installation of such a plant is not recommended at present for Lodgepole Valley, especially because pumping on a large scale would probably interfere with existing rights to the stream water.

The following data in regard to the pumping plant of Mr. Gus. Forsling in the NE. $\frac{1}{4}$ sec. 34 , T. 15 N., R. 57 W. (see p. 57), were obtained in part from the owner and in part by a test made on September 21, 1915. In its general features this plant is more or less typical of the pumping plants that are best adapted to the conditions in this valley. 
Data in regard to the pumping plant of Mr. Gus. Forsling, near Bushnell, Nebr.

Well, 31 feet deep, 14-inch casing below cement-lined pump pit, ending in gravel.

Pump, 5-inch vertical centrifugal.

Power, 18-horsepower gasoline engine.

Cost of well, pump, and engine, $\$ 867$.

Estimated total cost of plant, $\$ 1,000$.

Normal water level, below surface, 15 feet.

Normal water level, below discharge, 33 feet.

Drawdown, about 4 feet.

Total lift, about 37 feet.

Rated capacity of pump, about 1.5 second-feet.

Yield when tested, September 21, 1915, 1 second-foot.

Gasoline used, 12 gallons per hour.

Cost of gasoline, 12 cents per gallon.

Useful work accomplished (lifting 1 second-foot of water 37 feet), 4.2 horsepower.

Energy expended, counting 1 pint of gasoline per horsepower-hour, 13.3 horsepower.

Efficiency, 31.6 per cent.

Gasoline required to pump 1 acre-foot of water (1 second-foot during 12 hours), 20 gallons.

Cost of gasoline to pump 1 acre-foot, $\$ 2.40$.

In the preceding table the estimate of yield of water is based on a test of about 1 hour, made September 21, 1915, but the estimate of the consumption of gasoline is based on a run of 19 hours. If in the longer run the water table stood higher or the yield of the pump was more nearly its rated capacity the conclusions as to efficiency and cost per acre-foot may be somewhat vitiated. The price of gasoline has advanced since the test was made, but distillates costing less than 12 cents could be used. Where fuel is consumed in relatively small quantities kerosene, which is cheaper than gasoline, is frequently used. There are, of course, many other expenses besides the cost of the fuel, such as lubricants, repairs and renewals, labor, and fixed charges, such as taxes and interest on investment.

According to Mr. Forsling the plant will irrigate 1 acre in 2 hours, and one irrigation will serve to raise a crop of fully 1 ton of alfalfa. According to the above figures, such an irrigation would be only 2 inches deep, and even if the pump worked at its rated capacity it would be only 3 inches deep. This involves a much higher duty of water than is usually attained, even in regions having as much rainfall as Lodgepole Valley. On soil that is not too porous it should be possible on the average to raise a ton of alfalfa with one-half or two-thirds of an acre-foot of irrigation water, although frequently the amount used is greater. ${ }^{1}$ If the Forsling plant were operated 80 days during the irrigation season for an average of 12 hours a day it would yield 80 acre-feet of water, which, with a duty of two-thirds acre-foot per ton of alfalfa, would produce 120 tons of this hay.

1 Bark, D. H., Experiments on the economical use of irrigation water in Idaho: U. S. Dept. Agr. Bull. 339, 1916. 


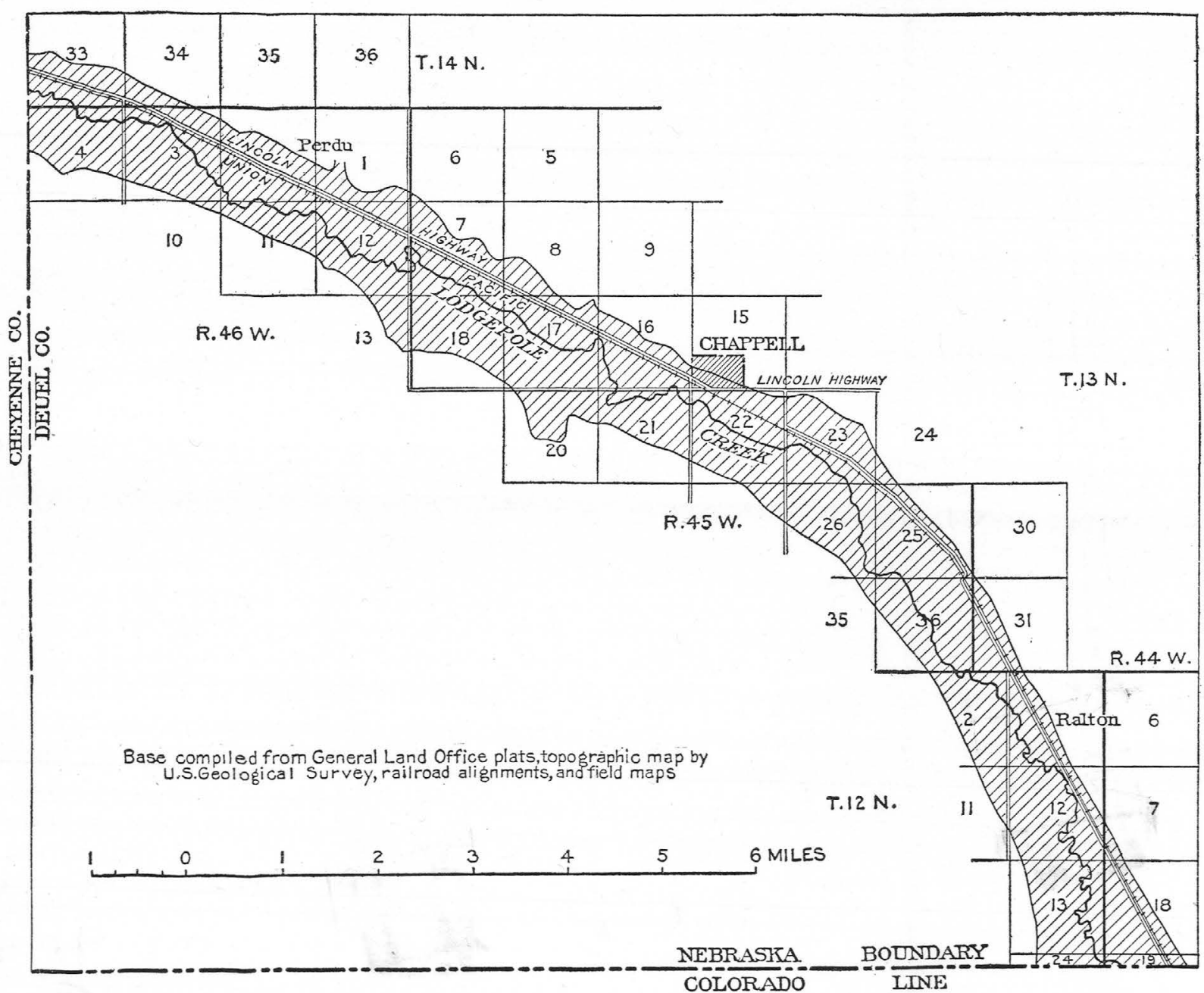

MAP OF LODGEPOLE VALLEY IN DEUEL COUNTY, NEBR., SHOWING GROUND-WATER CONDITIONS.

Area indicated by shading is underlain by water-bearing alluvium and has water table within about 25 feet of surface. Boundaries of valley are indefinite but are outside of area indicated by shading. Along Lodgepole Creek water table is practically at the surface. 
The data given above indicate a cost for fuel of $\$ 1.60$ for each ton of alfalfa raised. Assuming that interest and taxes amount to 9 per cent and that renewals, repairs, and other expenses amount to 15 per cent of the original investment of $\$ 1,000$, these items would add $\$ 2$ per ton, making a total cost of $\$ 3.60$ per ton, exclusive of the cost of labor in pumping and, of course, exclusive of the cost of planting the fields, applying the water, and harvesting the crop.

Wells yielding enough water for practical irrigation can be obtained in most parts of Lodgepole Valley, and the total irrigated area could be considerably increased by pumping. However, the area now irrigated is very large in comparison to the size of the stream; because ground water is supplied to the stream during the irrigation season. Extensive pumping of ground water would reduce the available supply of stream water, although the decrease in stream water would be less than the increase in pumped well water. Pumping on a moderate scale will probably not appreciably reduce the supply of stream - water and is doubtless practicable in Lodgepole Valley.

Flowing wells could probably be obtained by deep drilling in some parts of the valley, but the prospects are not encouraging for obtaining supplies from deep wells in quantities or at costs practicable for irrigation.

\section{COST OF PUMPING FOR IRRIGATION IN WESTERN NEBRASKA.}

By H. C. Diesem. ${ }^{1}$

During the growing season of 1914 the rainfall was 2.49 inches below normal in the northwestern part of Nebraska, 1.40 inches below in the western part, and 1.60 inches below in the southwestern part, and the general average rainfall for the western half of the State was 2.08 inches below the normal.

During this and the preceding dry seasons considerable interest was manifested in pumping, and numerous pumping plants were installed and operated throughout the State. In 1915 the precipitation was above the average, and none of the pumping plants were operated, but in the season of 1916 a drouth existed during the month of July and many of the plants were again operated.

The Division of Irrigation Investigations, Office of Public Roads and Rural Engineering, United States Department of Agriculture, obtained records of some of the pumping plants operated during the seasons of 1914 and 1916 but has not yet compiled the data for 1916 .

The records for 1914 have been arranged in the order of the cost of pumping an acre-foot per foot lift, which ranged from 4.35 cents

\footnotetext{
1 Division of Irrigation Investigations, Office of Public Roads and Rural Engineering, U. S. Department of Agriculture.
} 
to 13 cents. The operations during that season showed some very good runs, ranging from 81 to 600 hours for the season, at a total cost of operation, exclusive of labor, ranging from $\$ 36.19$ to $\$ 185.76$ for the season's pumping. The cost of pumping an acre-foot ranged from $\$ 1.502$ to $\$ 3.636$, but as the lift ranged from 28 to 45 feet a true comparison must be based on the cost of pumping an acre-foot per foot lift.

It is noteworthy that the maximum cost per acre-foot delivered was at a plant having one of the two lowest lifts. This fact can be due only to low efficiency of the plant. Though plant No. 1 delivered water at only 4.35 cents per acre-foot per foot lift, plants Nos. 2,3 , and 4 , operated at a higher cost, furnished water on the land at a lower cost not only per acre irrigated but also per acre-inch applied. This difference is explained by the fact that the lift on No. 1 was greater and that the actual quantity of water applied to the land under plant No. 1 was but a trifle less than that from No. 2 and greater than that from Nos. 3 and 4. Plant No. 1 was also handicapped by not having a well of sufficient capacity to supply the pump; and though the engine is supposedly self-governing, it was not operated to its full capacity but was speeded down, and the plant was run below its rated capacity to avoid drawing down the well and sucking air, and thus breaking the suction of the pump.

Results of operating certain pumping plants in Nebraska in 1914.

\begin{tabular}{|c|c|c|c|c|c|c|c|c|c|}
\hline \multicolumn{3}{|c|}{ Plant. } & • & \multicolumn{2}{|c|}{ Pumping. } & \multicolumn{3}{|c|}{ Cost. } & \multirow{2}{*}{$\begin{array}{c}\text { Area to } \\
\text { which } \\
\text { water was } \\
\text { applied } \\
\text { once. }\end{array}$} \\
\hline No. & Engine. & Pump.a & Lift. & Time. & Quantity. & $\begin{array}{l}\text { Total for } \\
\text { season. }\end{array}$ & $\begin{array}{l}\text { Per acre- } \\
\text { foot. }\end{array}$ & $\begin{array}{l}\text { Per acre- } \\
\text { foot per } \\
\text { foot lift. }\end{array}$ & \\
\hline 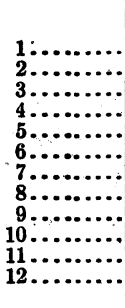 & \begin{tabular}{|r|} 
Horsepower. \\
25 \\
15 \\
25 \\
15 \\
20 \\
22 \\
15 \\
30 \\
15 \\
20 \\
18 \\
15
\end{tabular} & $\begin{array}{l}5 \mathrm{~T} \\
6 \mathrm{H} \\
6 \\
5 \mathrm{~V} \\
5 \mathrm{~V} \\
6 \mathrm{~V} \\
6 \mathrm{H} \\
5 \mathrm{H} \\
6 \mathrm{~V} \\
6 \mathrm{~V} \\
5 \mathrm{H} \\
5 \mathrm{H} \\
6 \mathrm{H}\end{array}$ & $\begin{array}{r}\text { Fiet. } \\
45 \\
34 \\
40 \\
40 \\
28 \\
31 \\
43 \\
\mathbf{4 3} \\
\mathbf{4 4} \\
\mathbf{4 5} \\
\mathbf{3 5} \\
\mathbf{3 3} \\
\mathbf{2 8} \\
\quad \mathbf{2 8} \\
\end{array}$ & $\begin{array}{rr}H . & m \\
436 & 35 \\
487 & 00 \\
116 & \\
155 \\
190 & 00 \\
128 & 00 \\
96 & 00 \\
600 & 25 \\
81 & 00 \\
355 & 30 \\
176 & 00 \\
151 & 00 \\
90 & 00\end{array}$ & \begin{tabular}{|r} 
Acre-feet. \\
40.11 \\
47.07 \\
19.68 \\
27.23 \\
18.88 \\
13.12 \\
80.06 \\
15.79 \\
26.96 \\
14.67 \\
14.23 \\
11.70
\end{tabular} & $\begin{array}{r}\$ 78.52 \\
70.69 \\
37.27 \\
43.65 \\
36.19 \\
36.40 \\
185.76 \\
54.11 \\
82.40 \\
43.48 \\
38.40 \\
42.54\end{array}$ & $\begin{array}{l}\$ 1.958 \\
1.502 \\
1.894 \\
1.603 \\
1.917 \\
2.774 \\
2.320 \\
3.426 \\
3.056 \\
2.962 \\
2.699 \\
3.636\end{array}$ & $\begin{array}{r}\text { Cents. } \\
4.35 \\
4.42 \\
4.74 \\
5.73 \\
6.18 \\
6.45 \\
7.25 \\
7.79 \\
8.73 \\
8.98 \\
9.63 \\
13.00\end{array}$ & $\begin{array}{c}\text { Acres. } \\
100 \\
104.6 \\
68 \\
63 \\
41.5 \\
35 \\
220 \\
60 \\
120 \\
48.5 \\
28 \\
20\end{array}$ \\
\hline
\end{tabular}

a Centrifugal pumps. Figure indicates number or size. $\mathrm{H}=$ horizontal, $\mathrm{V}=$ vertical, $\mathrm{T}=$ turbine.

The last column shows the number of acres to which water was applied once; for instance, plant No. 7 irrigated 110 acres twice, which is equivalent to irrigating 220 acres once.

The following table shows the number of times the crop was irrigated and the cost of applying the water to that crop: 
GROUND WATER IN LODGEPOLE VALLEY, WYO.-NEBR.

Number and cost of irrigations at certain pumping plants in Nebraska in 1914.

\begin{tabular}{|c|c|c|c|c|c|c|c|}
\hline \multirow[b]{2}{*}{ Plant No. } & \multirow[b]{2}{*}{$\begin{array}{c}\text { Crop irri- } \\
\text { gated. }\end{array}$} & \multirow[b]{2}{*}{$\begin{array}{c}\text { Area } \\
\text { irrigated, } \\
\text { in acres. }\end{array}$} & \multirow{2}{*}{$\begin{array}{l}\text { Num- } \\
\text { ber of } \\
\text { irriga- } \\
\text { tions. }\end{array}$} & \multicolumn{2}{|c|}{ Water applied. } & \multicolumn{2}{|c|}{ Cost. } \\
\hline & & & & $\begin{array}{l}\text { Total, in } \\
\text { acre-feet. }\end{array}$ & $\begin{array}{c}\text { Acre- } \\
\text { inches per } \\
\text { acre. }\end{array}$ & Per acre. & $\begin{array}{c}\text { Per } \\
\text { acre- } \\
\text { inch }\end{array}$ \\
\hline 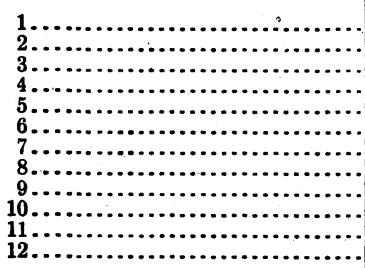 & 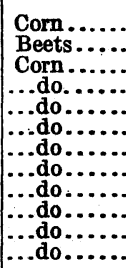 & $\begin{array}{r}40.0 \\
37.3 \\
25 \\
20 \\
10 \\
35 \\
110 \\
3 \\
60 \\
48 \\
12 \\
20\end{array}$ & $\begin{array}{l}\mathbf{2} \\
2 \\
2 \\
2 \\
2 \\
2 \\
1 \\
2 \\
\mathbf{3} \\
\mathbf{2} \\
\mathbf{1} \\
\mathbf{2} \\
\mathbf{1}\end{array}$ & $\begin{array}{r}30.29 \\
32.86 \\
14.62 \\
15.05 \\
9.38 \\
13.12 \\
80.06 \\
1.76 \\
26.96 \\
13.54 \\
10.66 \\
11.70\end{array}$ & $\begin{array}{r}9.09 \\
10.56 \\
7.02 \\
9.03 \\
11.25 \\
4.50 \\
16.01 \\
7.04 \\
5.39 \\
3.39 \\
10.66 \\
7.02\end{array}$ & $\begin{array}{l}\$ 1.482 \\
1.322 \\
1.104 \\
1.206 \\
1.754 \\
1.040 \\
1.689 \\
2.008 \\
1.373 \\
.835 \\
2.397 \\
2.127\end{array}$ & $\begin{array}{r}\$ 0.168 \\
.12 \% \\
.158 \\
.133 \\
.160 \\
.231 \\
.106 \\
.290 \\
.255 \\
.247 \\
.225 \\
.303\end{array}$ \\
\hline
\end{tabular}


